\title{
Cool Roofs as an Energy Conservation Measure for Federal Buildings
}

\author{
A document prepared for the \\ Federal Energy Management Program of the \\ U.S. Department of Energy \\ Haider Taha and Hashem Akbari \\ Heat Island Group \\ Lawrence Berkeley National Laboratory \\ Berkeley, California 94720
}

April 2003 


\section{TABLE OF CONTENTS}

Summary $\quad$ xi

1. Introduction

2. Impacts of roof albedo changes

3. Existing market of roofing systems and technology options

4. Representative building types used in this document

5. Representative weather types and data used in this document

6. Impacts of cool roofs on energy use in Federal buildings

6.1 Building-scale calculations

6.2 Regional/National scale calculations

6.3 The spreadsheet calculator

7. Cost effectiveness

8. Conclusions

9. References 


\section{Acknowledgements}

This work was supported by the Assistant Secretary for Energy Efficiency and Renewable Energy, Federal Energy Management Program, of the U.S. Department of Energy under Contract No. DE-AC03-76SF00098. 


\section{LIST OF TABLES}

Table 1: Selected cool-roof options for low-sloped roofs 3

Table 2. Available commercial building low-sloped roofing technologies 5

$\begin{array}{lll}\text { Table 3. Leading roofing product manufacturers } & 7\end{array}$

Table 4. Incremental cost for cool varieties of common low-sloped roofing 8 products

Table 5. Life expectancies of roofing materials 8

Table 6. Example weather types and data sources 10

Table 7. Assumed typical number of floors for federal building types 12

Table 8. Regression coefficients for predictive equations 13

Table 9. Saturation (\%) of HVAC for federal building categories and selected 17 weather/cities

Table 10. Assumed roof albedo and feasible increase in albedo 18

Table 11. Federal building type square footage by State 19

Table 12. Mapping of states and climate types for energy calculations 21

Table 13. Incremental costs and life spans of cool roofs 23

Table 14. Computed CCE for various combinations of roof life span and 25 incremental costs 


\title{
GLOSSARY
}

\begin{abstract}
Albedo $(\alpha)$ : For a flat surface, albedo is hemispheric- and wavelength-integrated reflectivity. Thus whereas reflectivity (see below) is the ratio of reflected to total incident radiative flux at a particular wavelength, albedo, by definition, encompasses a range of wavelengths of interest. In this document, we are interested mostly in solar albedo with an integral over the portion of the solar spectrum between about 0.3 and $3.0 \mu \mathrm{m}$. In this report, the terms "albedo" and "solar reflectance" are used interchangeably.
\end{abstract}

Absorptivity: The ratio of radiative flux absorbed at a certain wavelength to the total incident radiative flux.

Emissivity: The ratio of radiative flux emitted at a certain wavelength and temperature to that emitted by a black body under the same conditions.

Emittance: This is emissivity integrated over a certain wavelength range of interest.

Reflectivity: The ratio of radiative flux reflected at a certain wavelength to the total incident radiative flux.

Solar reflectance: In this document, it is defined as reflectivity integrated over the solar spectrum.

Solar absorptance (a): In this document, it is defined as absorptivity integrated over the solar spectrum. 


\section{SUMMARY}

The objective of this document is to develop initial estimates, for the Federal Energy Management Program, of the potential benefits of cool roofs on federal buildings and facilities as well as to extrapolate the results to national scale. In this document, regression equations are provided for use in estimating the energy and cost savings of cool roofs in specific federal building types and selected locations. In addition, the equations are also applied on a national basis to estimate nationwide savings. This will provide FEMP with a rationale for encouraging the use of this technology.

Thus along with this document, a preliminary spreadsheet "calculator" was devised to help FEMP estimate potential energy and cost savings of cool roofs (the calculator is on the floppy disk attached to this document). Entries in this calculator can be constantly updated as more region- and building-specific information becomes available. This document and companion calculator thus represents an initial step towards longer-term modeling of the potential benefits and implementation of cool roofs in FEMP facilities. In such possible future studies, specific Federal buildings may be analyzed and studied.

Based on the companion calculator, and for an average nation-wide insulation level of R-11 for roofs, it is estimated that nationwide savings in energy costs will amount to $\$ 16 \mathrm{M}$ and $\$ 32 \mathrm{M}$ for two scenarios of increased roof albedo (moderate and high), respectively. These savings correspond to about $3.8 \%$ and $7.5 \%$ of the base energy costs for FEMP facilities and include the increased heating energy use (penalties) in winter. This document also uses the cost of conserved energy (CCE) as a metric for assessing the cost effectiveness of cool roofs on Federal buildings. To keep the CCE under $\$ 0.08 \mathrm{kWh}^{-1}$ as a nationwide average, the calculations suggest that the incremental cost for cool roofs should not exceed $\$ 0.06 \mathrm{ft}^{-2}$, assuming that cool roofs have the same life span as non-cool roofs. However, cool roofs usually have extended life spans, e.g., 1530 years versus 10 years for conventional roofs, and thus the costs of re-roofing must be accounted for. When this is done, the cutoff incremental cost to keep CCE under $\$ 0.08 \mathrm{kWh}^{-1}$ can be much larger.

Incremental cost is defined in this document as the extra cost incurred because of selecting a cool roof instead of a non-cool version of the same. Of course, CCE varies significantly with building, location (state), and roof type. Thus a nationwide average, such as given above, may only give an order of magnitude indication. In addition to CCE, this document also provides a glimpse into generic results for residential and non-residential buildings from past studies that can be used to provide general indications as to the potential benefits of cool roofs in Federal buildings. 


\section{INTRODUCTION}

Over more than a decade, several studies, both experimental and numerical, have shown that cool roofs can reduce air-conditioning energy use (ACEU) by up to $50 \%$ depending on location, climate, building type, and thermal integrity of the building envelope. On a nationwide basis, including both residential and commercial building types, Akbari et al. $(1993,1997)$ estimate savings in the order of $\$ 750 \mathrm{M}$ per year in cooling energy bills. On a building scale, studies suggest significant energy savings and improvements in thermal comfort. For example, Parker et al. (1998) report savings of $13000 \mathrm{kWh} \mathrm{yr}^{-1}$ in ACEU (10\% reduction) and a peak demand reduction of 35\% in a Florida school building when its roof albedo was increased from 0.23 to 0.67. Parker et al. (1995) also report average savings (averaged over 9 monitored homes) of 7.4 $\mathrm{kWh} \mathrm{day}^{-1}$ (19\% reduction) and $0.4 \mathrm{~kW}$ (22\% reduction) in peak demand, when their roof albedos were increased.

In California, Akbari et al. (1997) report savings of $2.2 \mathrm{kWh}^{-1} \mathrm{day}^{-1}$ (80\% reduction) in ACEU and peak demand reductions of $0.6 \mathrm{~kW}$ (25\% reduction) when a cool roof was applied to a home in Sacramento. In a school bungalow in that same city, savings were $3.1 \mathrm{kWh}^{-1} \mathrm{de}^{-1}$ (35\% reduction) and $0.6 \mathrm{~kW}(20 \%$ reduction). In another field monitoring study of non-residential buildings (commercial, museum, and hospice) in Sacramento CA, Hildebrandt et al. (1998) report coolingenergy savings of $0.35-0.68 \mathrm{kWh} \mathrm{ft}^{-2} \mathrm{yr}^{-1}$ of treated roof as a result of using cool roofs. These savings correspond to reductions in the range of $17-39 \%$ in energy use.

Extensive DOE-2 energy modeling has shown significant savings from cool roofs in addition to other benefits. In most cases, the simulations even suggest that air-conditioners can be downsized as a result of implementing cool roof strategies. Of course, the actual benefits and disbenefits (e.g., heating penalty) will depend on the building type, loads, thermal integrity of the envelope, climate zone, and the level of modification (actual increase in roof albedo). In addition to energy benefits, cool roofs can have an indirect environmental impact, e.g., urban-scale cooling, reduced precursor air-pollutant emissions, and slower production of photochemical smog (Taha 1997, Taha et al. 1996,1999, 1992). Cool roofs also have structural advantages, for example, longer life spans and reduced maintenance needs (Bretz et al. 1997).

As a result of these demonstrated benefits, FEMP is looking into encouraging incorporation of cool roofs in Federal facilities, projects that it sponsors or in utility-financed energy retrofits. This document serves as an introductory blueprint for FEMP in formulating initial thinking about incorporating cool roofs in various aspects of its energy activities.

\section{IMPACTS OF ROOF ALBEDO CHANGES}

Dark roofs cause both direct and indirect effects, as explained in this section. Typical, dark roofing materials are efficient in absorbing incident solar radiation. For example, the majority of asphalt shingles typically have an albedo of between about 0.10 and 0.15 . Roofing membranes, such as black single-ply roofing have a typical albedo of 0.06 . Gravel roofs have albedos between 0.12 and 0.34 , depending on the color of the gravel, but most tend to be around 0.15 (Taha et al. 1992). More recently, Konopacki et al. (1997) estimate that the average roof albedo 
for existing residential and commercial buildings in Atlanta GA, Washington DC, and Philadelphia PA, is 0.25 .

Relatively dark roofs result in the direct effect of raising the roof temperature at a faster (larger) rate than reflective roofs. For example, Taha et al. (1992) show that light-colored roofs warm up at about $1 / 3$ the rate of their dark counterparts. As a consequence, the hotter roofs transmit more heat into the building than cooler ones, assuming that the insulation levels and construction are similar. Also, the difference between the temperature of the roof surface and that of the overlying air can be as high as $45-55 \mathrm{~K}\left(80-100^{\circ} \mathrm{F}\right)$ for dark roofs and as high as $10-15 \mathrm{~K}\left(20-30^{\circ} \mathrm{F}\right)$ for cool roofs, assuming similar underlying materials. During certain times, the surface temperature of cool roofs can be very close to that of ambient air. In another study, Parker et al. (1998) report a decrease of up to $29 \mathrm{~K}\left(52^{\circ} \mathrm{F}\right)$ in roof surface temperature (and $7 \mathrm{~K}$ on average) when a cool roof was installed on a school building in Florida.

Dark roofs also cause the indirect effect of warming the air in contact with them faster than the air in contact with cooler surfaces (of course the rate of air warming is much lower than that of the roof surface). On a neighborhood or city scale, this effect can add up and generate an urban heat island (UHI) of some $1-2 \mathrm{~K}$ as typical, and up to some $7 \mathrm{~K}$ as extreme. It is estimated that 5 $10 \%$ of the urban peak electric demand may be attributed to the UHI effect. For example, Rosenfeld et al. (1995) estimate that urban electric demand in certain warm U.S. cities increases by $2-4 \%$ for each $1 \mathrm{~K}$ increase in daily maximum temperature above $15^{\circ} \mathrm{C}$, in summer.

In this document, only the direct effects of cool roofs (as described above) will be discussed and quantified. But up to this point, these effects do not include impacts on lifetime of the roof. This additional benefit will be addressed later in this report.

\section{EXISTING MARKET OF ROOFING SYSTEMS AND TECHNOLOGY OPTIONS}

In general, roofs can be categorized as flat or low-sloped and as (steep) sloped, gable roofs. Roughly defined, low-sloped roofs are those with smaller than $10^{\circ}$ grades. In 2001 for commercial buildings, three types of roof products (built-up roofing (BUR), modified bitumen, and single-ply membrane) accounted for $83 \%$ of sales dollars (including labor) in the $\$ 6.0 \mathrm{~B}, 14$ state western U.S. market for low-sloped commercial-building roofing (Western Roofing, 2001). The 14 western states include AK, AZ, CA, CO, HI, ID, MT, NV, NM, OR, TX, UT, WA, and WY. The remaining $17 \%$ of the market was made up of metal, asphalt shingle, tile, polyurethane foam, liquid applied coatings, and other materials. By roof area, BUR (27\%), modified bitumen $(26 \%)$, and single-ply membrane $(22 \%)$ cover $75 \%$ of the western-region roof area. It may be reasonable to assume that the national roofing market bears resemblance to the 14-state market in terms of composition and makeup.

Nationwide, there are over 200 companies manufacturing roofing products, most of whom specialize in certain types of roofing. However, firms that manufacture asphalt-based roofing products, such as asphalt shingles, built-up roofing, and/or modified bitumen, are able to offer all three types of roofing systems. Companies that specialize in asphalt-based roofing have the largest sales volumes. Many roofing companies are eager to participate in the marketing of cool 
roofs. For example, the EPA Energy Star ${ }^{\circledR}$ roof program lists over 100 Roof Product Partners. The EPA program allows manufacturers to self-certify their products' performance criteria and thus an ample supply of eligible products should be readily available for low-sloped roofs, as summarized in Table 1.

Table 1: Selected cool-roof options for low-sloped roofs (Levinson et al., 2002).

\begin{tabular}{|c|c|c|c|}
\hline & $\begin{array}{c}\text { Solar } \\
\text { reflectance }\end{array}$ & Emittance & $\operatorname{Cost}\left(\$ \mathrm{ft}^{-2}\right)$ \\
\hline $\begin{array}{l}\text { Built-up Roof } \\
\text { with white gravel }\end{array}$ & $0.30-0.50$ & $0.80-0.90$ & $1.2-2.15$ \\
\hline $\begin{array}{l}\text { with gravel and } \\
\text { cementitious coating }\end{array}$ & $0.50-0.70$ & $0.80-0.90$ & \\
\hline $\begin{array}{l}\text { smooth surface } \\
\text { with white roof coating }\end{array}$ & $0.75-0.85$ & $0.85-0.95$ & \\
\hline $\begin{array}{l}\text { Single-Ply Membrane } \\
\text { white (EPDM, CPE, } \\
\text { CSPE, PVC) }\end{array}$ & $0.70-0.78$ & $0.85-0.95$ & $1.0-2.05$ \\
\hline $\begin{array}{l}\text { Modified Bitumen } \\
\text { white coating over a } \\
\text { mineral surface (SBS, } \\
\text { APP) }\end{array}$ & $0.60-0.75$ & $0.85-0.95$ & $1.5-1.95$ \\
\hline $\begin{array}{l}\text { Metal Roof } \\
\text { white painted }\end{array}$ & $0.60-0.70$ & $0.80-0.90$ & $1.8-3.75$ \\
\hline $\begin{array}{l}\text { Asphalt Shingle } \\
\text { white }\end{array}$ & $0.25-0.27$ & $0.80-0.90$ & $1.2-1.5$ \\
\hline $\begin{array}{l}\text { Liquid Applied } \\
\text { Coating } \\
\text { smooth white } \\
\text { smooth off-white } \\
\text { rough white }\end{array}$ & $\begin{array}{l}0.70-0.85 \\
0.40-0.60 \\
0.50-0.60 \\
\end{array}$ & $\begin{array}{l}0.85-0.95 \\
0.85-0.95 \\
0.85-0.95 \\
\end{array}$ & $0.6-0.8$ \\
\hline $\begin{array}{l}\text { Concrete Tile } \\
\text { white }\end{array}$ & $0.65-0.75$ & $0.85-0.90$ & $3-4$ \\
\hline with off-white coating & $0.65-0.75$ & $0.85-0.90$ & \\
\hline Clay Tile & & & $3-4$ \\
\hline $\begin{array}{l}\text { Cement Tile } \\
\text { white }\end{array}$ & $0.70-0.75$ & $0.85-0.90$ & $3-4$ \\
\hline
\end{tabular}


Table 2 lists the available commercial-building low-sloped roofing technologies and their market shares in the 14 Western states region (Western Roofing, 2001). For each type, a description is provided along with estimated average costs and percentage of market. In Table 3 , a listing of selected roofing product manufacturers is given (The Freedonia Group, 1997; Builder, 1995) along with its market share and a description of the product they specialize in.

Following that, Table 4 lists estimated incremental costs for cool varieties of common lowsloped roofing products. Incremental costs are defined in this document as the additional costs for a certain roofing type that are incurred as a result of selecting a cool-roof version of it. Finally, in Table 5, the life expectancy of selected roofing materials is given (NRCA, 1998; Lufkin and Pepitone, 1997). Data from tables 1 through 5 are used in an example application using the companion calculator to assess nationwide costs and benefits of implementing cool roofs in FEMP facilities and buildings. 
Table 2. Available commercial building low-sloped roofing technologies (Western Roofing, 2001 and Levinson et al., 2002).

\begin{tabular}{|c|c|c|c|c|}
\hline \multirow[b]{2}{*}{ Technology } & \multirow[b]{2}{*}{ Description } & \multirow{2}{*}{$\begin{array}{l}\operatorname{Cost}^{a} \\
\left(\$ \mathrm{ft}^{-2}\right) \\
\end{array}$} & \multicolumn{2}{|c|}{ WESTERN } \\
\hline & & & Sales & Area $^{b}$ \\
\hline $\begin{array}{l}\text { Built-up Roof } \\
\text { (BUR) }\end{array}$ & $\begin{array}{l}\text { A continuous, semi-flexible multi-ply roof membrane, consisting of plies } \\
\text { (layers) of saturated felts, coated felts, fabric, or mats, between which } \\
\text { alternate layers of bitumen are applied. (Bitumen is a tarlike hydrocarbon } \\
\text { mixture often including nonmetallic hyrocarbon derivatives; it may be } \\
\text { obtained naturally or from the residue of heat-refining natural substances such } \\
\text { as petroleum.) Built-up roof membranes are typically surfaced with roof } \\
\text { aggregate and bitumen, a liquid-applied coating, or a granule-surfaced cap } \\
\text { sheet. }\end{array}$ & 1.7 & $31 \%$ & $27 \%$ \\
\hline $\begin{array}{l}\text { Modified } \\
\text { Bitumen }\end{array}$ & $\begin{array}{l}\text { (1) A bitumen modified through the inclusion of one or more polymers (e.g., } \\
\text { atactic polypropylene and/or styrene butadiene styrene). } \\
\text { (2) Composite sheets consisting of a polymer modified bitumen often } \\
\text { reinforced and sometimes surfaced with various types of mats, films, foils, } \\
\text { and mineral granules. It can be classified into two categories: thermoset, and } \\
\text { thermoplastic. A thermoset material solidifies or sets irreversibly when } \\
\text { heated; this property is usually associated with cross-linking of the molecules } \\
\text { induced by heat or radiation. A thermoplastic material softens when heated } \\
\text { and hardens when cooled; this process can be repeated provided that the } \\
\text { material is not heated above the point at which decomposition occurs. }\end{array}$ & 1.7 & $30 \%$ & $26 \%$ \\
\hline \multirow[t]{2}{*}{ Examples } & $\begin{array}{l}\text { Styrene-butadiene styrene (SBS) is an elastomeric modifier containing high } \\
\text { molecular weight polymers with both thermoset and thermoplastic properties. } \\
\text { It is formed by the block copolymerization of styrene and butadiene } \\
\text { monomers. These polymers are used as modifying compound in SBS polymer } \\
\text { modified asphalt-roofing membranes to impart rubber-like qualities to the } \\
\text { asphalt. }\end{array}$ & & $13 \%$ & \\
\hline & $\begin{array}{l}\text { Atactic polypropylene (APP) is a thermoplastic modifier containing a group } \\
\text { of high molecular weight polymers formed by the polymerization of } \\
\text { propylene. Used in modified bitumen as a plastic additive to permit heat } \\
\text { fusing (torching). }\end{array}$ & & $17 \%$ & \\
\hline $\begin{array}{l}\text { Single-Ply } \\
\text { Membrane }\end{array}$ & $\begin{array}{l}\text { A roofing membrane that is field applied using just one layer of membrane } \\
\text { material (either homogeneous or composite) rather than multiple layers. The } \\
\text { principal roof covering is usually a single-layer flexible membrane, often of } \\
\text { thermoset, thermoplastic, or polymer-modified bituminous compounds. } \\
\text { Roofing membranes can be torch-applied or hot-mopped with asphalt during } \\
\text { application. }\end{array}$ & 1.5 & $23 \%$ & $22 \%$ \\
\hline \multirow[t]{3}{*}{ Examples } & $\begin{array}{l}\text { Ethylene-propylene-diene monomer (EPDM) is the ASTM-designated name } \\
\text { for an elastomeric single-ply roofing membrane containing a terpolymer of } \\
\text { ethylene, propylene, and diene. EPDM is a thermosetting synthetic } \\
\text { elastomer-that is, a macromolecular material that returns to its approximate } \\
\text { initial dimensions and shape after substantial deformation by a weak stress } \\
\text { and the subsequent release of that stress. }\end{array}$ & & $9.0 \%$ & \\
\hline & $\begin{array}{l}\text { Polyvinyl chloride (PVC) is a synthetic thermoplastic polymer prepared from } \\
\text { vinyl chloride. PVC can be compounded into flexible and rigid forms through } \\
\text { the use of plasticizers, stabilizers, fillers, and other modifiers. Flexible forms } \\
\text { are used in the manufacture of sheeting and roof membrane materials. }\end{array}$ & & $6.3 \%$ & \\
\hline & $\begin{array}{l}\text { Thermoplastic olefin (TPO) is a blend of polypropylene and ethylene- } \\
\text { propylene polymers. Colorants, flame-retardants, UV absorber, and other } \\
\text { proprietary substances may be blended with TPO to achieve the desired } \\
\text { physical properties. The membrane may or may not be reinforced. }\end{array}$ & & $6.3 \%$ & \\
\hline
\end{tabular}




\begin{tabular}{|c|c|c|c|c|}
\hline \multirow[b]{2}{*}{ Technology } & \multirow[b]{2}{*}{ Description } & \multirow{2}{*}{$\begin{array}{l}\operatorname{Cost}^{a} \\
\left(\$ \mathrm{ft}^{-2}\right) \\
\end{array}$} & \multicolumn{2}{|c|}{ WESTERN } \\
\hline & & & Sales & Area $^{b}$ \\
\hline & $\begin{array}{l}\text { Chlorosulfonated polyethylene (CSPE) is a synthetic, rubber-like thermoset } \\
\text { material, based on high molecular weight polyethylene with sulphonyl } \\
\text { chloride, that is usually formulated to produce a self-vulcanizing membrane. It } \\
\text { is best known by the DuPont trade name HypalonTM. }\end{array}$ & & $1.0 \%$ & \\
\hline Metal & Metal roofs can be classified as architectural or structural. & 2.7 & $5.2 \%$ & $2.8 \%$ \\
\hline Examples & $\begin{array}{l}\text { Architectural (hydrokinetic-watershedding) standing-seam roof systems are } \\
\text { typically used on steep slopes with relatively short panel lengths. They usually } \\
\text { do not have sealant in the seam because they are designed to shed water } \\
\text { rapidly. They do not provide structural capacity or load resistance, and their } \\
\text { installation is less labor-intensive because they have a solid substrate platform } \\
\text { that makes installation easier. }\end{array}$ & & $2.8 \%$ & \\
\hline & $\begin{array}{l}\text { Structural (hydrostatic-watershedding) standing-seam roof systems are } \\
\text { versatile metal panel systems that can be used on both steep- and low-slope } \\
\text { roofs .Most structural standing-seam systems include a factory-applied sealant } \\
\text { in the standing seams to help ensure water tightness. These panel systems } \\
\text { provide structural capacity and load resistance. }\end{array}$ & & $2.4 \%$ & \\
\hline $\begin{array}{l}\text { Asphalt } \\
\text { Shingle }\end{array}$ & $\begin{array}{l}\text { Asphalt is a dark brown to black cementitious material, solid or semisolid, in } \\
\text { which the predominant constituents are naturally-occurring or petroleum- } \\
\text { derived bitumens. It is used as a weatherproofing agent. The term asphalt } \\
\text { shingle is generically used for both fiberglass and organic shingles. There are } \\
\text { two grades of asphalt shingles: (1) standard, a.k.a. 3-tab, and (2) architectural, } \\
\text { a.k.a. laminated or dimensional. Asphalt shingles come in various colors }\end{array}$ & 1.3 & $3.6 \%$ & $4.2 \%$ \\
\hline Examples & $\begin{array}{l}\text { Fiberglass shingles, commonly known as "asphalt shingles," consist of fiber } \\
\text { mats that are coated with asphalt and then covered with granules. Granules, } \\
\text { a.k.a. mineral granules or ceramic granules, are opaque, naturally or } \\
\text { synthetically colored aggregates commonly used to surface cap sheets and } \\
\text { shingles. }\end{array}$ & & $3.6 \%$ & \\
\hline & $\begin{array}{l}\text { Organic shingles have a thick cellulose base that is saturated in soft asphalt. } \\
\text { This saturation makes them heavier than fiberglass shingles, and less resistant } \\
\text { to heat and humidity, but more durable in freezing conditions. }\end{array}$ & & $\mathrm{n} / \mathrm{a}$ & \\
\hline Tile & $\begin{array}{l}\text { Usually made of concrete or clay, tile is a combination of sand, cement, and } \\
\text { water; the water fraction depends on the manufacturing process. Concrete tiles } \\
\text { are either air-cured or auto-claved, whereas clay tiles are kiln-fired. Color is } \\
\text { added to the surface of the tile with a slurry coating process, or added to the } \\
\text { mixture during the manufacturing process. }\end{array}$ & 3.5 & $0.3 \%$ & $0.1 \%$ \\
\hline $\begin{array}{l}\text { Polyure-thane } \\
\text { Foam (SPF) }\end{array}$ & $\begin{array}{l}\text { A foamed plastic material, formed by spraying two components (Polymeric } \\
\text { Methelene Diisocyanate [PMDI] and a resin) to form a rigid, fully adhered, } \\
\text { water-resistant, and insulating membrane. }\end{array}$ & 0.7 & $2.5 \%$ & $5.2 \%$ \\
\hline $\begin{array}{l}\text { Liquid } \\
\text { Applied } \\
\text { Coatings }\end{array}$ & $\begin{array}{l}\text { These are used as a surfacing on roofs of various types, especially built-up } \\
\text { and metal roofs. They are available in different colors, and may be divided on } \\
\text { the basis of reflectivity into black, aluminum, white, and tinted coatings. }\end{array}$ & 0.4 & $2.5 \%$ & $9.2 \%$ \\
\hline Other & $\begin{array}{l}\text { All other roofing materials that are not covered under the categories } \\
\text { mentioned above. }\end{array}$ & 1 & $2.1 \%$ & $3.1 \%$ \\
\hline
\end{tabular}

a. LBNL estimates of the typical material and labor costs are approximate.

$b$. LBNL's estimates of roof areas fractions are derived from product market shares and costs. 
Table 3. Leading roofing product manufacturers (The Freedonia Group, 1997; Builder, 1995).

\begin{tabular}{|c|c|c|c|c|}
\hline Company & $\begin{array}{l}\text { Market } \\
\text { Share }\end{array}$ & Leader In & Product Mix & Sales \\
\hline Owens Corning & $8 \%$ & asphalt-based roofing & $\begin{array}{c}\text { multi-product } \\
\text { building materials }\end{array}$ & $\begin{array}{l}\text { local dealer/distributor and } \\
\text { factory-direct }\end{array}$ \\
\hline GAF Materials Corporation & $7 \%$ & asphalt-based roofing & $\begin{array}{c}\text { multi-product } \\
\text { building materials }\end{array}$ & no information \\
\hline $\begin{array}{l}\text { France-based Saint-Gobain } \\
\text { (via CertainTeed) }\end{array}$ & $6 \%$ & asphalt-based roofing & $\begin{array}{l}\text { multi-product } \\
\text { building materials }\end{array}$ & local dealer/distributor \\
\hline Jim Walter (via Celotex) & $3-4 \%$ & $\begin{array}{l}\text { asphalt-based roofing, } \\
\text { coatings }\end{array}$ & $\begin{array}{l}\text { multi-product } \\
\text { building materials }\end{array}$ & local dealer/distributor \\
\hline GS Roofing Products & $3-4 \%$ & asphalt-based roofing & specialty & local dealer/distributor \\
\hline Johns Manville & $3-4 \%$ & asphalt-based roofing & $\begin{array}{c}\text { multi-product } \\
\text { building materials }\end{array}$ & $\begin{array}{l}\text { local dealer/distributor and } \\
\text { factory-direct }\end{array}$ \\
\hline $\begin{array}{l}\text { Carlisle Companies (via } \\
\text { Carlisle SynTec) }\end{array}$ & $3-4 \%$ & elastomeric roofing & $\begin{array}{l}\text { multi-line rubber } \\
\text { products; metal } \\
\text { roofing }\end{array}$ & no information \\
\hline $\begin{array}{l}\text { Japan-based Bridgestone (via } \\
\text { Firestone Building Products) }\end{array}$ & $3-4 \%$ & elastomeric roofing & $\begin{array}{l}\text { multi-line rubber } \\
\text { products; building } \\
\text { materials }\end{array}$ & no information \\
\hline Tamko Roofing Products & $<3 \%$ & asphalt-based roofing & specialty & local dealer/distributor \\
\hline $\begin{array}{l}\text { United Dominion Industries } \\
\text { (via AEP Span and Varco- } \\
\text { Pruden Buildings) }\end{array}$ & $<3 \%$ & metal roofing & $\begin{array}{l}\text { specialty pre- } \\
\text { engineered buildings }\end{array}$ & no information \\
\hline Gulf States Manufacturers & $<3 \%$ & metal roofing & $\begin{array}{c}\text { specialty pre- } \\
\text { engineered buildings }\end{array}$ & no information \\
\hline NCI Building Systems & $<3 \%$ & metal roofing & $\begin{array}{l}\text { specialty pre- } \\
\text { engineered buildings }\end{array}$ & no information \\
\hline $\begin{array}{l}\text { Australia-based Boral (via } \\
\text { US Tile and Lifetile) }\end{array}$ & $<3 \%$ & tile & no information & local dealer/distributor \\
\hline Clarke Group of Canada & $<3 \%$ & $\begin{array}{l}\text { cedar shingles and } \\
\text { shakes; fiber cement } \\
\text { roofing }\end{array}$ & no information & no information \\
\hline Elcor (via Elk) & $<3 \%$ & asphalt shingles & no information & local dealer/distributor \\
\hline GenCorp & $<3 \%$ & $\begin{array}{l}\text { thermoplastic and rubber } \\
\text { membrane roofing }\end{array}$ & no information & no information \\
\hline Hood Companies & $<3 \%$ & $\begin{array}{l}\text { asphalt shingles and roll } \\
\text { roofing }\end{array}$ & no information & no information \\
\hline $\begin{array}{l}\text { Redland of the UK (via } \\
\text { Monier Roof Tile) }\end{array}$ & $<3 \%$ & tile & no information & local dealer/distributor \\
\hline Tremco & $<3 \%$ & $\begin{array}{l}\text { built-up and membrane } \\
\text { roofing }\end{array}$ & no information & no information \\
\hline
\end{tabular}


Table 4. Incremental cost for cool varieties of common low-sloped roofing products (Levinson et al., 2002).

\begin{tabular}{|l|l|l|}
\hline Roofing Product & Cool Variety & Cost Premium $\mathbf{( \$ / f ^ { 2 }}$ ) \\
\hline ballasted BUR & use white gravel & up to 0.05 \\
BUR with smooth asphalt coating & use cementitious or other white coatings & 0.10 to 0.20 \\
BUR with aluminum coating & use cementitious or other white coatings & 0.10 to 0.20 \\
single-ply membrane (EPDM, TPO, CSPE, & choose a white color & 0.00 to 0.05 \\
PVC) & use a white coating over the mineral surface & up to 0.05 \\
modified bitumen (SBS, APP) & use a white or cool color paint & 0.00 to 0.05 \\
metal roofing (both painted and unpainted) & use a white or cool color coating & 0.00 to 0.10 \\
roof coatings (dark color, asphalt base) & use a white or cool color & 0.00 to 0.05 \\
concrete tile & use a white or cool color & 0.05 \\
cement tile (unpainted) & use cool red tiles & 0.10 \\
red clay tile &
\end{tabular}

The values in the third column of Table 4 represent increases in cost over that of conventional roofs of similar construction. For reference, the costs of conventional roof types are as follows (typical average values): $1.2-2.1 \$ / \mathrm{ft}^{2}$ for built-up roofs, $1-2 \$ / \mathrm{ft}^{2}$ for single-ply membrane, 1.5-1.9 $\$ / \mathrm{ft}^{2}$ for modified bitumen, 1.8-3.7 $\$ / \mathrm{ft}^{2}$ for metal roofs, 1.1-1.4 $\$ / \mathrm{ft}^{2}$ for asphalt shingles, and 3-4 \$/ $\mathrm{ft}^{2}$ for concrete tiles (Levinson et al., 2002).

Table 5. Life expectancies of roof materials (NRCA, 1998; Lufkin and Pepitone, 1997).

\begin{tabular}{|c|c|}
\hline Roofing material & Life expectancy (yr) \\
\hline wood shingles and shakes & 15 to 30 \\
tile & 50 \\
slate & 50 to 100 \\
sheet metal & 20 to $50+$ \\
BUR/asphalt & 12 to 25 \\
BUR/coat and tar & 12 to 30 \\
single-ply modified bitumen & 10 to 20 \\
single-ply thermoplastic & 10 to 20 \\
single-ply thermoset & 10 to 20 \\
asphalt shingle & 15 to 30 \\
asphalt overlay & 25 to 35 \\
\hline
\end{tabular}

\section{REPRESENTATIVE BUILDING TYPES USED IN THIS DOCUMENT}

This document was prepared to provide an initial estimate of potential benefits of cool roofs on Federal buildings. The estimates are based on previous field work and numerical studies and resulting regression equations. Thus the results provided in this document rely implicitly on 
certain building types that were used in past modeling and analysis work. The combination of studies and building types used in the past forms the basis for an "in-house" knowledge database that can be drawn upon, e.g., in this document. In this section, generic building prototypes used past modeling and analysis efforts are briefly described, focusing on a generic "residential" and a generic "non-residential" building. In the future, specific Federal building types should be characterized and simulated based on detailed prototypes developed accordingly. For more information, see Konopacki et al. (1997).

\subsection{RESIDENTIAL BUILDINGS}

The representative prototypical residential building is a single-family structure with a floor area of $150 \mathrm{~m}^{2}\left(\sim 1610 \mathrm{ft}^{2}\right)$. The roof material consists of $1 / 4$ " asphalt shingle, $1 / 2$ " plywood, with an attic cavity and an R-11 insulation. The ceiling is $1 / 2$ " gypsum board. The walls are 1" stucco, with R-7 insulation and $1 / 2$ " gypsum. Windows have one pane of clear glass and a shading coefficient of 0.86 . Occupancy of 3 people is assumed. Cooling is achieved with a packaged direct-expansion air-cooled system with a COP of 2.1 and a temperature set point of $25^{\circ} \mathrm{C}\left(78^{\circ} \mathrm{F}\right)$. Heating is done with either a forced-air natural gas furnace with $70 \%$ efficiency or an electric heat pump with a $\mathrm{COP}$ of 2.1. Both have a set point of $21^{\circ} \mathrm{C}\left(70^{\circ} \mathrm{F}\right)$ and a setback of $3.5^{\circ} \mathrm{C}\left(6.5^{\circ} \mathrm{F}\right)$. Equipment capacities vary depending on geographical area, building age, and climate.

\subsection{NON-RESIDENTIAL BUILDINGS}

The buildings include types such as offices, retail stores, schools, hospitals, nursing homes, and grocery stores. The typical floor area ranges from about 400 to $13000 \mathrm{~m}^{2}$ ( 4300 to $\left.139700 \mathrm{ft}^{2}\right)$ and the number of floors from 1 to 7 . The roofing materials are mostly built-up roofs with $1 / 2$ inch plywood, attic space, and an R-11 overall insulation level. Beneath that, there is either $1 / 2$ inch gypsum or acoustic tiles. The walls are either a combination of stucco, plywood, insulation and gypsum, or a combination of concrete blocks (hollow or filled), insulation, and gypsum. The wall insulation is typically R-7. Windows are all one pane and clear, with a shading coefficient of 0.86. Internal loads and occupancy schedules vary from one region to another. Cooling is achieved mostly through packaged direct-expansion air-cooled systems with some buildings using hermetic centrifugal chillers with air-cooled cooling towers. A COP of 2.1 is assumed and an enthalpic ventilation scheme is adopted. The set point is at $26^{\circ} \mathrm{C}\left(78^{\circ} \mathrm{F}\right)$. Heating is done with forced-air natural gas systems and sometimes with electric heat pumps. The efficiency of the natural gas systems is $70 \%$ and the electrical heat pump's COP is 2.1 . The heating set point is mostly around $21^{\circ} \mathrm{C}\left(70^{\circ} \mathrm{F}\right)$ with a set back of about $8^{\circ} \mathrm{C}\left(14^{\circ} \mathrm{F}\right)$. When comparing results from a building that has a different COP than listed above, for example, the results should be adjusted by the ratio of the COPs.

\section{REPRESENTATIVE WEATHER TYPES AND DATA USED IN THIS DOCUMENT}

Table 6 only provides some examples of weather data sources and related characteristics as used in some of the relevant DOE-2 simulations done in the past to estimate the benefits of cool roofs. These are given here to provide an idea of the data types used for this application. Data sources include Typical Meteorological Years (TMY), Weather Years for Energy Calculations (WYEC), 
and related cooling or heating degree-days (CDD, HDD). Auxiliary information includes meteorological conditions such as cloud cover and latent enthalpy hours.

Table 6. Example weather types and sources used in past energy modeling work.

\begin{tabular}{|l|l|l|l|l|l|}
\hline & Data format & $\begin{array}{l}\text { HDD } \\
\left(18^{\circ} \mathrm{C}\right)\end{array}$ & $\begin{array}{l}\text { CDD } \\
\left(18^{\circ} \mathrm{C}\right)\end{array}$ & $\begin{array}{l}\text { Latent } \\
\text { enthalpy } \\
\text { hours }\end{array}$ & $\begin{array}{l}\text { Mean sky } \\
\text { cover }\end{array}$ \\
\hline Atlanta & WYEC-2 & 3215 & 1602 & 4931 & .495 \\
\hline Chicago & WYEC-2 & 6425 & 1105 & 2781 & .492 \\
\hline Los Angeles & TMY & 2238 & 1198 & 109 & .588 \\
\hline Dallas & WYEC-2 & 2604 & 2649 & 7951 & .536 \\
\hline Houston & TMY & 1580 & 2883 & 18845 & .480 \\
\hline Miami & WYEC-2 & 283 & 4011 & 27753 & .506 \\
\hline New Orleans & TMY & 1526 & 2610 & 17754 & .511 \\
\hline New York & WYEC-2 & 5029 & 1076 & 1533 & .465 \\
\hline Philadelphia & TMY-2 & 5297 & 1146 & 3168 & .461 \\
\hline Phoenix & WYEC-2 & 1672 & 4044 & 967 & .686 \\
\hline WDC & WYEC & 4410 & 1494 & 3734 & .472 \\
\hline
\end{tabular}

\section{IMPACTS OF COOL ROOFS ON ENERGY USE IN FEDERAL BUILDINGS}

In this section, a method for evaluating the potential energy impacts of cool roofs in Federal buildings and facilities is addressed at two scales: 1) building scale and 2) nationwide estimates. In addition, some tabulated data are given for comparison reference in estimating potential benefits of cool roofs. Section 6.1 summarizes the building-scale calculations whereas section 6.2 summarizes the regional ones.

\section{$\underline{\text { 6.1 Building-Scale Calculations }}$}

This section provides a simplified tool, e.g., regression equations, that can be used to estimate the potential energy and cost savings from cool roofs in Federal buildings at given locations/climates (or at locations similar to any ones given in this document). The regression equations (Akbari et al. 1998) rely on a set of coefficients $\left(\mathrm{C}_{\mathrm{i}}\right)$ that currently distinguish between residential and nonresidential buildings and among a number of selected climates. Application of this tool at this time will require use of this limited information. However, if more detailed building types are sought in the future, or if new building- and location-specific data are developed, these coefficients could be updated and made more specific and used accordingly. Note that the results obtained from applying these equations represent the direct effect only, as defined earlier in this document. That is, they account only for the envelope (not air temperature) effects of cool roofs.

Thus this section provides the following:

1) A step-by-step description of how this tool can be used to derive savings estimates (6.1.1)

2) A general assessment of confidence and related margin of errors in using this tool (6.1.2) 
3) Example application of this tool (6.1.3)

\subsubsection{Application (step-by-step description).}

Equations (1) and (2) can be used in an initial assessment of potential building-scale energy benefits. In theory, these equations could be used when specific building information is available, or in general when building prototype information is known but not specific to a certain building. Either way, the following steps should be followed in general:

\section{CHART 1.}

\begin{tabular}{|c|c|}
\hline $\begin{array}{r}\text { Specific building is known } \\
\text { STEPS } \downarrow\end{array}$ & $\begin{array}{c}\text { Prototypical calculation (no specific building) } \\
\text { STEPS } \downarrow\end{array}$ \\
\hline $\begin{array}{l}\text { 1. Calculate total roof area (the total area to which a cool } \\
\text { roof will be applied) }\end{array}$ & $\begin{array}{l}\text { 1. Assume the most reasonable value for 'A' (the total floor } \\
\text { area of the building) and estimate ' } N \text { ' (the number of floors) } \\
\text { or obtain it from Table } 7 \text {. Divide A by N to estimate roof } \\
\text { area. Or, alternatively, if possible, directly estimate or } \\
\text { assume the roof area that will receive a cool roof }\end{array}$ \\
\hline $\begin{array}{l}\text { 2. Identify building type (residential or non-residential), } \\
\text { see NOTE } 1 \text {, below }\end{array}$ & $\begin{array}{l}\text { 2. Identify building type (residential or non-residential), see } \\
\text { NOTE } 1 \text {, below }\end{array}$ \\
\hline $\begin{array}{l}\text { 3. Determine the overall, effective U-factor (U) based on } \\
\text { construction data and engineering drawings and } \\
\text { specifications of the building in question, see NOTE } 2 \text {, } \\
\text { below }\end{array}$ & $\begin{array}{l}\text { 3. Estimate or assume some reasonable value for effective } \\
\text { U-factor (U) based on building type and related } \\
\text { information, see NOTE 2, below }\end{array}$ \\
\hline $\begin{array}{l}\text { 4. Determine the initial absorptance (a) of the existing } \\
\text { roof, via field-measurement, e.g., with a pyranometer or } \\
\text { the like, or material specification. }\end{array}$ & $\begin{array}{l}\text { 4. Estimate or assume the absorptance }(a) \text { of the existing } \\
\text { roof using entries from Table 10, column } 2 \text { (recall } a=1- \\
\alpha \text { ). }\end{array}$ \\
\hline $\begin{array}{l}\text { 5. Identify the climate type or location of the building in } \\
\text { Table } 8 \text {, Column } 1 \text {. If the location or climate of interest } \\
\text { is not explicitly listed in Table } 8 \text {, use Table } 12 \text { to "map" } \\
\text { or select the State of interest into the corresponding } \\
\text { climate type. That is, find your State in columns } 1 \text { or } 3 \text {, } \\
\text { and identify the matching entry in columns } 2 \text { or } 4 \text {. }\end{array}$ & $\begin{array}{l}\text { 5. Identify the climate type or location of the building in } \\
\text { Table } 8 \text {, Column } 1 \text {. If the location or climate of interest is } \\
\text { not explicitly listed in Table } 8 \text {, use Table } 12 \text { to "map" or } \\
\text { select the State of interest into the corresponding climate } \\
\text { type. That is, find your State in columns } 1 \text { or } 3 \text {, and } \\
\text { identify the matching entry in columns } 2 \text { or } 4 \text {. }\end{array}$ \\
\hline $\begin{array}{l}\text { 6. From Table } 8 \text {, select the values of coefficients Co } \\
\text { through C } 3 \text { (from column } 4 \text { or } 5 \text { ) for the building type, } \\
\text { location, and system (heating or cooling) as identified in } \\
\text { steps } 2 \text { and } 5 \text { above. }\end{array}$ & $\begin{array}{l}\text { 6. From Table } 8 \text {, select the values of coefficients Co } \\
\text { through C } 3 \text { (from column } 4 \text { or } 5 \text { ) for the building type, } \\
\text { location, and HVAC system (heat or cool) as identified in } \\
\text { steps } 2 \text { and } 5 \text { above. }\end{array}$ \\
\hline $\begin{array}{l}\text { 7. Use the coefficients obtained in step } 6 \text { along with the } \\
\text { U-factor and absorptance (a) obtained in steps } 3 \text { and } 4 \\
\text { above, use them in equation (2) to compute } F(i, j, k) \text {, see } \\
\text { NOTE } 4 \text {. }\end{array}$ & $\begin{array}{l}\text { 7. Use the coefficients obtained in step } 6 \text { along with the U- } \\
\text { factor and absorptance (a) obtained in steps } 3 \text { and } 4 \text { above, } \\
\text { use them in equation (2) to compute F(i,j,k), see NOTE } 4 \text {. }\end{array}$ \\
\hline $\begin{array}{l}\text { 8. Multiply the value of } \mathrm{F}(\mathrm{i}, \mathrm{j}, \mathrm{k}) \text { obtained in step } 7 \text { by the } \\
\text { actual or assumed roof area obtained in step } 1 \text { above, to } \\
\text { obtain energy use }(\mathrm{E}(\mathrm{i}, \mathrm{jk})) \text {, see NOTE } 4 \text {. }\end{array}$ & $\begin{array}{l}\text { 8. Multiply the value of } F(\mathrm{i}, \mathrm{j}, \mathrm{k}) \text { obtained in step } 7 \text { by the } \\
\text { actual or assumed roof area obtained in step } 1 \text { above, to } \\
\text { obtain energy use }(\mathrm{E}(\mathrm{i}, \mathrm{jk})) \text {, see NOTE } 4 \text {. }\end{array}$ \\
\hline $\begin{array}{l}\text { 9. Calculate energy costs. For electricity, multiply E by } \\
\text { the local rate } \$ / \mathrm{kWh} \text { and for gas, multiply E by the local } \\
\text { rate for } \$ / \text { therm. }\end{array}$ & $\begin{array}{l}\text { 9. Calculate energy costs. For electricity, multiply E by the } \\
\text { local rate } \$ / \mathrm{kWh} \text { and for gas, multiply E by the local rate } \\
\text { for } \$ / \text { therm. If the local rates are not available, use } \\
\$ 0.08 / \mathrm{kWh} \text { and } \$ 0.65 / \text { therm (national averages). }\end{array}$ \\
\hline $\begin{array}{l}\text { 10. Repeat steps } 4,7,8 \text {, and } 9 \text { with a different value of } \\
\text { (a) that corresponds to a cool roof to estimate the post- } \\
\text { retrofit energy use as a result of implementing the cool } \\
\text { roof on a building of interest. See NOTE } 3 \text {. Then } \\
\text { subtracts the post-retrofit use from the pre-retrofit use to } \\
\text { get savings. }\end{array}$ & $\begin{array}{l}\text { 10. Repeat steps } 4,7,8 \text {, and } 9 \text { with a different value of (a) } \\
\text { that corresponds to a cool roof to estimate the savings in } \\
\text { energy use as a result of implementing cool roofs on a } \\
\text { building of interest. See NOTE } 3 \text {. }\end{array}$ \\
\hline
\end{tabular}


NOTE 1: In this application of the tool, the distinction is made generally between residential and non-residential buildings. Obviously, this can be improved upon in the future by addressing a large number of building types and categories. This of course will require an explicit study of specific federal buildings throughout the U.S.

NOTE 2: Some common value for the U-factor (for use in equation 2) are: $0.1734,0.0726$, and 0.0245 which correspond to insulation levels R3, R11, and R38, respectively. Note that $U=1 / R$ but the values above do not correspond exactly to each other due to nominal differences between R-value of insulation vs. U-value for the roof assembly.

NOTE 3: An example calculation is given in subsection 6.1.3, below.

NOTE 4: Steps 7 and 8 must be done twice; once for electricity and once for gas.

In applying equations (1) and (2), $\mathrm{E}(\mathrm{i}, \mathrm{j}, \mathrm{k})$ is annual energy use ( $\mathrm{kWh}$ for electricity or therms for gas) for city/climate "i", building-type " $j$ ", and HVAC system " $k$ ". In equation (2), $U$ is the overall U-factor of the roof construction and a is absorptance $(a=1-\alpha)$. These values can be obtained or estimated as discussed above. The equations are (terms are defined below):

$$
\begin{gathered}
E(\mathrm{i}, \mathrm{j}, \mathrm{k})=\mathrm{F}(\mathrm{i}, \mathrm{j}, \mathrm{k}) \times \mathrm{A}(\mathrm{j}) / \mathrm{N}(\mathrm{j}) \\
\mathrm{F}(\mathrm{i}, \mathrm{j}, \mathrm{k})=\mathrm{C}_{\mathrm{o}}(\mathrm{i}, \mathrm{j}, \mathrm{k})+\mathrm{C}_{1}(\mathrm{i}, \mathrm{j}, \mathrm{k}) \mathrm{a}+\mathrm{C}_{2}(\mathrm{i}, \mathrm{j}, \mathrm{k}) \mathrm{U}+\mathrm{C}_{3}(\mathrm{i}, \mathrm{j}, \mathrm{k}) \mathrm{U} \text { a }
\end{gathered}
$$

Where, depending on the way they are applied, E and F can be 1) annual electricity usage (kWh $\left.\mathrm{yr}^{-1}\right), 2$ ) annual gas energy use (therms $\left.\mathrm{yr}^{-1}\right)$, or 3) net energy use $\left(\$ \mathrm{yr}^{-1}\right)$. In these equations, $\mathrm{A}(\mathrm{j})$ is the total square footage of the building (j) in question and $\mathrm{N}(\mathrm{j})$ is the number of floors for Federal building type (j) from Table 7. Of course, if $\mathrm{A}$ and $\mathrm{N}$ are actually known (building specific), or if roof area is directly known, then they should be used explicitly in the equations. The net energy costs are computed as $\Sigma_{\mathrm{k}} \mathrm{E}(\mathrm{i}, \mathrm{j}, \mathrm{k})$.

Table 7. Assumed typical number of floors for Federal building types.

\begin{tabular}{|l|l|}
\hline FEMP building type (j) & $\begin{array}{l}(\mathrm{N}) \text { \# of Floors } \\
\text { (assumed average) }\end{array}$ \\
\hline Hospital & 4 \\
\hline Housing & 2 \\
\hline Industrial & 1 \\
\hline Office & 2.5 \\
\hline Prison & 2 \\
\hline Other & 2 \\
\hline R\&D & 2.5 \\
\hline School & 1.5 \\
\hline Services & 1 \\
\hline Storage & 1.5 \\
\hline Utility & 1 \\
\hline
\end{tabular}


Table 8 (columns 4 and 5) provides the values of the regression coefficients for use in equations (1) and (2). In developing these coefficients, it was found that the corresponding $\mathrm{R}^{2}$ values were better than 0.99 except for a handful of cases. These $\mathrm{R}^{2}$ values are also listed in column 3 in the table. Note that the coefficients are exact for the locations given in column 1 of the table. For 'mapped' locations, e.g., from columns 1 and 3 in Table 12, a significant and unknown amount of error may be introduced. These issues should be considered very carefully when applying and using equations (1) and (2).

Table 8. Regression coefficients for equations (1) and (2).

\begin{tabular}{|c|c|c|c|c|c|c|c|c|c|c|}
\hline \multirow{3}{*}{$\begin{array}{l}1 \\
\text { City/Climate (i) }\end{array}$} & 2 & \multirow{3}{*}{$\begin{array}{l}3 \\
\mathrm{R}^{2} \\
\text { Res/non-Res }\end{array}$} & \multicolumn{4}{|l|}{4} & \multicolumn{4}{|l|}{5} \\
\hline & & & \multicolumn{4}{|c|}{ Residential (j) } & \multicolumn{4}{|c|}{ Non-residential (j) } \\
\hline & & & $\mathrm{C}_{\mathrm{o}}$ & $\mathrm{C}_{1}$ & $\mathrm{C}_{2}$ & $\mathrm{C}_{3}$ & $\mathrm{C}_{\mathrm{o}}$ & $\mathrm{C}_{1}$ & $\mathrm{C}_{2}$ & $\mathrm{C}_{3}$ \\
\hline \multirow[t]{2}{*}{ Honolulu } & cool & $1.00 / 1.00$ & 5.091 & -.353 & -7.328 & 37.579 & 5.21 & .03 & -2.617 & 21.384 \\
\hline & heat & $0.96 / 0.94$ & -.0 & .0 & .004 & -.003 & -.0 & .0 & .01 & -.007 \\
\hline \multirow[t]{2}{*}{ Miami } & cool & $1.00 / 1.00$ & 5.154 & -.318 & -5.334 & 39.364 & 5.169 & .047 & -1.723 & 23.238 \\
\hline & heat & $0.99 / 1.00$ & -.001 & .001 & .082 & -.065 & .0 & .001 & .074 & -.03 \\
\hline \multirow[t]{2}{*}{ Tampa } & cool & $1.00 / 1.00$ & 4.219 & -.179 & -3.558 & 32.583 & 4.5 & .083 & -1.152 & 20.056 \\
\hline & heat & $0.99 / 1.00$ & .0 & .004 & .27 & -.2 & .003 & .001 & .222 & -.085 \\
\hline \multirow[t]{2}{*}{ Phoenix } & cool & $1.00 / 1.00$ & 4.948 & -.355 & 1.671 & 44.914 & 4.774 & .078 & 1.276 & 29.219 \\
\hline & heat & $0.99 / 1.00$ & -.0 & .004 & .502 & -.401 & .009 & .001 & .398 & -.156 \\
\hline \multirow[t]{2}{*}{ Lake Charles } & cool & $1.00 / 1.00$ & 4.115 & -.248 & -3.361 & 36.687 & 4.211 & .018 & -1.379 & 22.002 \\
\hline & heat & $1.00 / 1.00$ & .017 & .004 & .595 & -.46 & .012 & .003 & .396 & -.162 \\
\hline \multirow[t]{2}{*}{ San Diego } & Cool & $1.00 / 1.00$ & 2.644 & -.227 & -6.598 & 30.033 & 2.904 & .095 & -3.837 & 18.416 \\
\hline & heat & $0.97 / 1.00$ & -.009 & .011 & .428 & -.4 & .001 & .002 & .348 & -.143 \\
\hline \multirow[t]{2}{*}{ Fort Worth } & cool & $1.00 / 1.00$ & 4.136 & -.259 & -.339 & 32.299 & 3.998 & .049 & .416 & 19.207 \\
\hline & heat & $1.00 / 1.00$ & .036 & .006 & .864 & -.611 & .024 & .003 & .568 & -.225 \\
\hline \multirow[t]{2}{*}{ San Bernardino } & cool & $1.00 / 1.00$ & 3.232 & -.152 & -3.308 & 35.228 & 3.481 & .099 & -2.329 & 23.352 \\
\hline & heat & $0.99 / 1.00$ & .002 & .008 & .868 & -.693 & .014 & .003 & .69 & -.28 \\
\hline \multirow[t]{2}{*}{ Atlanta } & cool & $1.00 / 1.00$ & 3.166 & -.182 & -4.422 & 31.908 & 3.304 & .065 & -2.547 & 19.618 \\
\hline & heat & $1.00 / 1.00$ & .054 & .006 & 1.15 & -.754 & .032 & .003 & .79 & -.319 \\
\hline \multirow[t]{2}{*}{ San Francisco } & cool & $1.00 / 1.00$ & 1.731 & -.224 & -2.627 & 22.224 & 1.906 & .035 & -2.107 & 12.79 \\
\hline & heat & $0.99 / 1.00$ & .011 & .015 & 1.367 & -1.210 & .018 & .003 & .803 & -.329 \\
\hline \multirow[t]{2}{*}{ Amarillo } & cool & $1.00 / 1.00$ & 3.202 & -.273 & -2.764 & 37.751 & 3.127 & -.003 & -1.581 & 19.015 \\
\hline & heat & $1.00 / 1.00$ & .083 & .008 & 1.57 & -.998 & .055 & .004 & 1.056 & -.0406 \\
\hline \multirow[t]{2}{*}{ Portland } & cool & $1.00 / 1.00$ & 2.066 & -.065 & -1.211 & 18.128 & 2.104 & .048 & -1.152 & 12.541 \\
\hline & heat & $1.00 / 1.00$ & .095 & .005 & 1.65 & -.909 & .045 & .005 & 1.154 & -.45 \\
\hline \multirow[t]{2}{*}{ Seattle } & cool & $1.00 / 1.00$ & 1.872 & -.142 & -2.377 & 18.024 & 1.829 & .035 & -1.591 & 11.824 \\
\hline & heat & $1.00 / 1.00$ & .109 & .008 & 1.942 & -1.107 & .05 & .006 & 1.307 & -.52 \\
\hline \multirow[t]{2}{*}{ Boise } & cool & $1.00 / 1.00$ & 2.688 & -.162 & -1.06 & 27.32 & 2.644 & .046 & -.64 & 17.271 \\
\hline & heat & $1.00 / 1.00$ & .127 & .005 & 2.028 & -.1246 & .073 & .005 & 1.404 & -.608 \\
\hline \multirow[t]{2}{*}{ Vancouver } & cool & $0.99 / 1.00$ & 1.722 & -.01 & -2.795 & 16.816 & 1.743 & .035 & -2.884 & 12.125 \\
\hline & heat & $1.00 / 1.00$ & .119 & .005 & 2.052 & -1.13 & .057 & .005 & 1.413 & -.557 \\
\hline \multirow[t]{2}{*}{ Minneapolis } & cool & $0.99 / 1.00$ & 2.342 & -.038 & 3.306 & 15.862 & 2.464 & .040 & -1.107 & 13.382 \\
\hline & heat & $1.00 / 1.00$ & .264 & .001 & 2.502 & -.88 & .155 & -.0 & 1.871 & -.546 \\
\hline Halifax & cool & $0.99 / 1.00$ & 1.823 & -.131 & -1.305 & 19.955 & 1.875 & .009 & -2.197 & 13.594 \\
\hline & heat & $1.00 / 1.00$ & .226 & .006 & 2.696 & -1.343 & .122 & .002 & 1.994 & -.751 \\
\hline Bismarck & cool & $0.99 / 1.00$ & 2.403 & -.020 & 1.131 & 20.015 & 2.375 & .038 & -1.123 & 14.146 \\
\hline & heat & $1.00 / 1.00$ & .289 & .0 & 2.88 & -1.038 & .179 & .0 & 2.068 & -.56 \\
\hline Anchorage & cool & $0.99 / 1.00$ & 1.537 & .125 & 3.604 & 7.374 & 1.428 & .067 & -1.244 & 8.638 \\
\hline & heat & $1.00 / 1.00$ & .337 & -.005 & 3.253 & -.988 & .203 & -.004 & 2.355 & -.546 \\
\hline Edmonton & cool & $0.99 / 1.00$ & 1.898 & .04 & 2.855 & 13.905 & 1.77 & .074 & -1.050 & 11.371 \\
\hline & heat & $1.00 / 1.00$ & .340 & -.001 & 3.392 & -1.234 & .222 & -.003 & 2.423 & -.654 \\
\hline
\end{tabular}


In Table 8, the coefficients have the following units: A) for cooling, $\mathrm{C}_{0}$ and $\mathrm{C}_{1}$ have units of $\mathrm{kWh} / \mathrm{ft}^{2}$, whereas $\mathrm{C}_{2}$ and $\mathrm{C}_{3}$ have units of $\mathrm{hr}-\mathrm{F}^{\circ}, \mathrm{B}$ ) for heating, $\mathrm{C}_{\mathrm{o}}$ and $\mathrm{C}_{1}$ have units of $10^{5}$ $\mathrm{Btu} / \mathrm{ft}^{2}$, whereas $\mathrm{C}_{2}$ and $\mathrm{C}_{3}$ have units of $10^{5} \mathrm{hr}-\mathrm{F}^{\circ}$.

Thus if a climate of interest is not found explicitly in column 1 of Table 8, one needs to select a location that has a climate generally similar to the desired one. For this purpose, Table $\mathbf{1 2}$ could be used in a very approximate manner, whereby a desired State (in columns 1 or 3 ) can be mapped into a location given in columns 2 or 4 which then correspond to entries in column 1 of Table 8 above. Thence, the coefficients of the location of interest can be obtained from columns 4 or 5 in Table 8.

Once the heating and cooling energies have been computed, the costs can be obtained by using the local rates, i.e., the cost of $\mathrm{kWh}$ electricity and therms of natural gas. If these rates are unknown for the locality of interest, national averages could be used instead, e.g., $\$ 0.08 \mathrm{kWh}^{-1}$ and $\$ 0.65$ therm $^{-1}$.

\subsubsection{Expected confidence interval/error margin}

In column 3 of Table 8, values for the coefficient of correlation $\left(\mathrm{R}^{2}\right)$ are given for each region (columns 1), building type (columns 4 and 5) and HVAC system (column2) that were simulated in previous studies. These values are based on the simulations of Akbari et al. (1998) and all of them, except two entries, are equal to or better than 0.99 . This would suggest that the application of equations (1) and (2) for the regions given in columns 1 of Table 8 should involve a minimum or no error. These $\mathrm{R}^{2}$ values relate to simulated results, not field observations or actual buildingmonitoring data. However, the main use of these results would be to find the relative change in energy use. Thus we recommend the use of equations (1) and (2) in a relative sense, to assess the order of magnitude of potential savings from application of cool roofs on Federal buildings, but not for computing the absolute energy use in such buildings.

When using equations (1) and (2), one must also consider that the entries in column 3 of Table 8 are valid only with respect to the locations and climates given in the corresponding entries in column 1. When mapping entries from columns 1 and 3 in Table 12, these correlation factors are no longer valid and as a result, the error introduced into the calculations are unknown.

\subsubsection{Example application of the tool}

In this section an example calculation is given. Let's assume that we are evaluating the effectiveness of cool roofs on a hypothetical non-residential building (small office) in Huntsville, Alabama (the choice is arbitrary). The building has a total floor area of $18,000 \mathrm{ft}^{2}$.

Step 1. Since the building is hypothetical, we'll use the steps on he right side of Chart 1. Thus $\mathrm{A}=18000 \mathrm{ft}^{2}$ and from Table 7, $\mathrm{N}=2.5$ (line 4). Thus $\mathrm{A} / \mathrm{N}=7200 \mathrm{ft}^{2}$ (the estimated roof area). 
Step 2. The building is an office (non-residential) thus we will use entries in column 5 of Table 8.

Step 3. Based on some information, let's assume that the roof construction has an effective insulation level corresponding to R-11. Thus $\mathrm{U}=0.0726$.

Step 4. Again, since the building is hypothetical, no observational values from albedo or absorptivity are available. Thus we need to use Table 10. From column 2, the albedo is 0.20 . Thus absorptivity is roughly, $\mathrm{a}=1-0.20=0.80$, which is the "base-case" value for the noncool hypothetical roof.

Step 5. Since Huntsville, Alabama is not listed in column 1 of Table 8, we will need to look it up in Table 12. We can locate Alabama in column 3 of Table 12 and see that the representative climate for mapping is that of Atlanta (column 4 of Table 12).

Step 6. Thus the coefficients we need are those under Column 5 in Table 8, corresponding to Atlanta. The values are $3.304,0.065,-2.547$, and 19.618 for electricity and $0.032,0.003,0.79$, and -0.319 for gas.

Step 7. Use the values of coefficients above in equation (2). For this example, the computed value for ' $\mathrm{F}$ ' is $4.31 \mathrm{kWh} \mathrm{yr}^{-1} \mathrm{ft}^{-2}$ for electricity and 0.0732 therms $\mathrm{yr}^{-1} \mathrm{ft}^{-2}$ for gas.

Step 8. Find the total annual energy use by multiplying the results from step 7 by the roof area obtained in Step 1. Thus the annual electricity usage is $4.31 \times 7200=31000 \mathrm{kWh} \mathrm{yr}^{-1}$ and annual gas usage is $0.0732 \times 7200=527$ therms $\mathrm{yr}^{-1}$.

Step 9. Calculate the energy costs. Since local rates are not available for this example, we'll use the national averages. Thus the electricity cost is $31000 \times 0.08=\$ 2480 \mathrm{yr}^{-1}$ and for gas, the cost is $572 \times 0.65=\$ 340 \mathrm{yr}^{-1}$. The total annual energy cost is thus $\$ 2800 \mathrm{yr}^{-1}$.

Now, we repeat steps 4, 7, 8, and 9 (these will be labeled 4', 7', 8', and 9' below) with a different albedo value to estimate the reduction in energy costs as a result of cool roofs. For this example, let us assume that the level of modification of roof albedo is high. Thus from Table 10 (column 6), the new albedo for office building is 0.60 (of course if building-specific data are available, they should be used instead). Thus absorptivity $=1-0.60=0.40$.

Step 4'. The new absorptivity for the cool roof is 0.40 (note that we assume the same construction and thus the same U-factor as in the base case).

Step 7'. The computed values for cool roof ' $\mathrm{F}$ ' is $3.71 \mathrm{kWh} \mathrm{yr}^{-1} \mathrm{ft}^{-2}$ for electricity and 0.081 therms $\mathrm{yr}^{-1} \mathrm{ft}^{-2}$ for gas. Note that cooling energy use has decreased compared to the base case whereas heating energy use has increased.

Step 8'. Total annual electricity usage is $3.71 \times 7200=26700 \mathrm{kWh} \mathrm{yr}^{-1}$ and annual gas usage is $0.081 \times 7200=580$ therms $\mathrm{yr}^{-1}$. 
Step 9'. Thus for the cool-roof scenario, the electricity cost is $26700 \times 0.08=\$ 2100 \mathrm{yr}^{-1}$ and for gas, the cost is $583 \times 0.65=\$ 380 \mathrm{yr}^{-1}$. The total annual energy cost is thus $\$ 2500 \mathrm{yr}^{-1}$.

SAVINGS: Thus the net cost savings for this hypothetical building are $\$ 2800 \mathrm{yr}^{-1}-\$ 2500 \mathrm{yr}^{-1}=$ $\$ 300 \mathbf{~ y r}^{-1}$, which is a net reduction of $\mathbf{1 1 \%}$ in annual energy costs. Of course this is a relatively small building and the absolute savings are small accordingly. However, as will be discussed in Section 7, there are other savings from cool roofs, such as increased life span and avoided maintenance and replacement costs (which can be very significant). The $\mathbf{\$ 3 0 0} \mathbf{y r}^{-1}$ are only the energy savings.

\subsection{Regional/National Scale Calculations}

To estimate the potential nationwide energy benefits of cool roofs in Federal buildings and facilities, equations (1) and (2) are expanded further and recast as equations (3) and (4) below, as explained in this section. For this nationwide extrapolation exercise, the FEMP facility and Federal building type distribution information was obtained directly from FEMP (www.eren.doe.gov/femp/facilitydata). The information available from FEMP includes the number of buildings by category and the total square footage. No indication for number of floors is given. Furthermore, the data is segregated by U.S. regional breakdown, i.e., 1) Northeast, 2) Mid Atlantic, 3) Southeast, 4) Midwest, 5) Central, and 6) Western.

In order to use equations (3) and (4), certain information must be known (or assumed) as was shown in Chart 1 above as well as some additional information. This includes 1) the typical average number of floors for each building category, 2) the saturation of HVAC equipment (heating and cooling systems) for each building type, and 3) the assumed albedo increase per building type. In addition to varying by building type, some parameters can also vary by state, location, and climate. Thus in the present calculations, some simplifying assumptions were made. In Tables 9, 10, and 11, some of these assumptions and information are given.

In Table 9, the assumed HVAC saturation for selected climates and Federal building types is given, for use in equations (3) and (4). For heating systems, the saturation is a sum of gas and heat pump systems. Also, since there is no exact match between FEMP building types (listed in this document) and previously modeled building types, the saturations given here are those corresponding to building types closest to the FEMP types. In Table 9, "c" is saturation of cooling equipment and " $h$ " is heating equipment saturation (\%). For housing and office categories the saturations given in Table 9 are averages of old and new building types. HVAC saturation for heating equipment (where there are old and new buildings) is the total of gas and heat pump then averaged again over old and new building types. 
Table 9: Saturation (\%) of HVAC for Federal building categories and selected weather/cities.

\begin{tabular}{|c|c|c|c|c|c|c|c|c|c|c|c|c|}
\hline $\begin{array}{c}\text { FEMP } \\
\text { building } \\
\text { category } \\
\downarrow\end{array}$ & & $\begin{array}{l}\text { 吾 } \\
\text { 坖 }\end{array}$ & 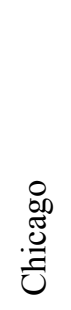 & 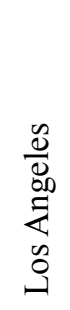 & $\frac{\mathscr{n}}{\overline{\bar{\sigma}}}$ & 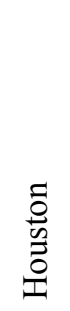 & $\stackrel{\vec{\Xi}}{\stackrel{\Xi}{\Sigma}}$ & 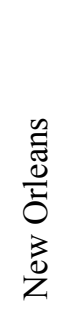 & $\begin{array}{l}\frac{y}{0} \\
\dot{z} \\
z \\
z\end{array}$ & 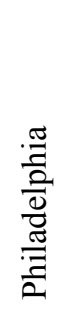 & $\begin{array}{l}\stackrel{x}{ \pm} \\
\frac{0}{0} \\
\frac{0}{2}\end{array}$ & $\stackrel{\circlearrowright}{3}$ \\
\hline Hospital & $\begin{array}{l}\text { Cool } \\
\text { Heat }\end{array}$ & $\begin{array}{l}100 \\
98\end{array}$ & $\begin{array}{l}86 \\
98\end{array}$ & $\begin{array}{l}100 \\
84\end{array}$ & $\begin{array}{l}40 \\
100\end{array}$ & $\begin{array}{l}40 \\
100\end{array}$ & $\begin{array}{l}100 \\
98\end{array}$ & $\begin{array}{l}40 \\
100\end{array}$ & $\begin{array}{l}51 \\
85\end{array}$ & $\begin{array}{l}51 \\
85\end{array}$ & $\begin{array}{l}100 \\
100\end{array}$ & $\begin{array}{l}100 \\
98\end{array}$ \\
\hline Housing & $\begin{array}{l}\text { Cool } \\
\text { Heat }\end{array}$ & $\begin{array}{l}83 \\
100\end{array}$ & $\begin{array}{l}62 \\
100\end{array}$ & $\begin{array}{l}44 \\
100\end{array}$ & $\begin{array}{l}88 \\
100\end{array}$ & $\begin{array}{l}85 \\
100\end{array}$ & $\begin{array}{l}85 \\
100\end{array}$ & $\begin{array}{l}77 \\
100\end{array}$ & $\begin{array}{l}26 \\
100\end{array}$ & $\begin{array}{l}55 \\
100\end{array}$ & $\begin{array}{l}91 \\
100\end{array}$ & $\begin{array}{l}84 \\
100\end{array}$ \\
\hline Industrial & $\begin{array}{l}\text { Cool } \\
\text { Heat }\end{array}$ & $\begin{array}{l}40 \\
40 \\
\end{array}$ & $\begin{array}{l}30 \\
60 \\
\end{array}$ & $\begin{array}{l}35 \\
50 \\
\end{array}$ & $\begin{array}{l}40 \\
40 \\
\end{array}$ & $\begin{array}{l}40 \\
40 \\
\end{array}$ & $\begin{array}{l}45 \\
40 \\
\end{array}$ & $\begin{array}{l}45 \\
40 \\
\end{array}$ & $\begin{array}{l}35 \\
50 \\
\end{array}$ & $\begin{array}{l}30 \\
50 \\
\end{array}$ & $\begin{array}{l}40 \\
40 \\
\end{array}$ & $\begin{array}{l}30 \\
50\end{array}$ \\
\hline Office & $\begin{array}{l}\text { Cool } \\
\text { Heat }\end{array}$ & $\begin{array}{l}100 \\
100\end{array}$ & $\begin{array}{l}97 \\
100\end{array}$ & $\begin{array}{l}96 \\
100\end{array}$ & $\begin{array}{l}100 \\
100\end{array}$ & $\begin{array}{l}100 \\
100\end{array}$ & $\begin{array}{l}100 \\
100\end{array}$ & $\begin{array}{l}100 \\
100\end{array}$ & $\begin{array}{l}95 \\
100\end{array}$ & $\begin{array}{l}95 \\
100\end{array}$ & $\begin{array}{l}100 \\
100\end{array}$ & $\begin{array}{l}100 \\
100\end{array}$ \\
\hline Prison & $\begin{array}{l}\text { Cool } \\
\text { Heat }\end{array}$ & $\begin{array}{l}60 \\
100\end{array}$ & $\begin{array}{l}60 \\
100\end{array}$ & $\begin{array}{l}30 \\
100\end{array}$ & $\begin{array}{l}60 \\
100\end{array}$ & $\begin{array}{l}60 \\
100\end{array}$ & $\begin{array}{l}60 \\
100\end{array}$ & $\begin{array}{l}60 \\
100\end{array}$ & $\begin{array}{l}30 \\
100\end{array}$ & $\begin{array}{l}40 \\
100\end{array}$ & $\begin{array}{l}60 \\
100 \\
\end{array}$ & $\begin{array}{l}60 \\
100\end{array}$ \\
\hline Other & $\begin{array}{l}\text { Cool } \\
\text { Heat }\end{array}$ & $\begin{array}{l}100 \\
100\end{array}$ & $\begin{array}{l}97 \\
100 \\
\end{array}$ & $\begin{array}{l}96 \\
100 \\
\end{array}$ & $\begin{array}{l}100 \\
100 \\
\end{array}$ & $\begin{array}{l}100 \\
100 \\
\end{array}$ & $\begin{array}{l}100 \\
100 \\
\end{array}$ & $\begin{array}{l}100 \\
100 \\
\end{array}$ & $\begin{array}{l}95 \\
100 \\
\end{array}$ & $\begin{array}{l}95 \\
100\end{array}$ & $\begin{array}{l}100 \\
100 \\
\end{array}$ & $\begin{array}{l}100 \\
100 \\
\end{array}$ \\
\hline R\&D & $\begin{array}{l}\text { Cool } \\
\text { Heat }\end{array}$ & $\begin{array}{l}100 \\
100 \\
\end{array}$ & $\begin{array}{l}97 \\
100 \\
\end{array}$ & $\begin{array}{l}96 \\
100 \\
\end{array}$ & $\begin{array}{l}100 \\
100 \\
\end{array}$ & $\begin{array}{l}100 \\
100 \\
\end{array}$ & $\begin{array}{l}100 \\
100 \\
\end{array}$ & $\begin{array}{l}100 \\
100 \\
\end{array}$ & $\begin{array}{l}95 \\
100 \\
\end{array}$ & $\begin{array}{l}95 \\
100 \\
\end{array}$ & $\begin{array}{l}100 \\
100 \\
\end{array}$ & $\begin{array}{l}100 \\
100 \\
\end{array}$ \\
\hline School & $\begin{array}{l}\text { Cool } \\
\text { Heat }\end{array}$ & $\begin{array}{l}99 \\
72\end{array}$ & $\begin{array}{l}74 \\
99\end{array}$ & $\begin{array}{l}63 \\
90\end{array}$ & $\begin{array}{l}95 \\
94\end{array}$ & $\begin{array}{l}95 \\
94\end{array}$ & $\begin{array}{l}99 \\
72\end{array}$ & $\begin{array}{l}95 \\
94\end{array}$ & $\begin{array}{l}85 \\
95\end{array}$ & $\begin{array}{l}85 \\
95\end{array}$ & $\begin{array}{l}98 \\
89\end{array}$ & $\begin{array}{l}99 \\
72\end{array}$ \\
\hline Services & $\begin{array}{l}\text { Cool } \\
\text { Heat }\end{array}$ & $\begin{array}{l}71 \\
100\end{array}$ & $\begin{array}{l}69 \\
100\end{array}$ & $\begin{array}{l}85 \\
100\end{array}$ & $\begin{array}{l}79 \\
100\end{array}$ & $\begin{array}{l}79 \\
100\end{array}$ & $\begin{array}{l}71 \\
100\end{array}$ & $\begin{array}{l}79 \\
100\end{array}$ & $\begin{array}{l}69 \\
100\end{array}$ & $\begin{array}{l}69 \\
100\end{array}$ & $\begin{array}{l}69 \\
100\end{array}$ & $\begin{array}{l}71 \\
100\end{array}$ \\
\hline Storage & $\begin{array}{l}\text { Cool } \\
\text { Heat }\end{array}$ & $\begin{array}{l}10 \\
15\end{array}$ & $\begin{array}{l}5 \\
20\end{array}$ & $\begin{array}{l}5 \\
15\end{array}$ & $\begin{array}{l}10 \\
10\end{array}$ & $\begin{array}{l}10 \\
10\end{array}$ & $\begin{array}{l}5 \\
10\end{array}$ & $\begin{array}{l}5 \\
10\end{array}$ & $\begin{array}{l}5 \\
20\end{array}$ & $\begin{array}{l}5 \\
20\end{array}$ & $\begin{array}{l}10 \\
10\end{array}$ & $\begin{array}{l}5 \\
15\end{array}$ \\
\hline Utility & $\begin{array}{l}\text { Cool } \\
\text { Heat }\end{array}$ & $\begin{array}{l}10 \\
15\end{array}$ & $\begin{array}{l}5 \\
20\end{array}$ & $\begin{array}{l}5 \\
15\end{array}$ & $\begin{array}{l}10 \\
10 \\
\end{array}$ & $\begin{array}{l}10 \\
10 \\
\end{array}$ & $\begin{array}{l}5 \\
10 \\
\end{array}$ & $\begin{array}{l}5 \\
10 \\
\end{array}$ & $\begin{array}{l}5 \\
20 \\
\end{array}$ & $\begin{array}{l}5 \\
20 \\
\end{array}$ & $\begin{array}{l}10 \\
10 \\
\end{array}$ & $\begin{array}{l}5 \\
15 \\
\end{array}$ \\
\hline
\end{tabular}

In Table 9, categories "hospital", "housing", and "school" have directly corresponding entries from previous research (for example, Akbari et al 1998) that addressed these types. The remaining categories in Table 9 had no equivalent entries. As a result, category "R\&D" was assigned the same entries as "office". Category "services" was assigned values from retail buildings (using new retail facilities from Akbari et al 1998). All other remaining categories were estimated for the purpose of this document. The same applies to weather or state. Thus when calculating nation-wide potential energy savings with equations (3) and (4), each state from the FEMP inventory should be matched to the closest weather type from the list of cities that were studied in the past. This approach was followed in developing the companion spreadsheet calculator (it was also explained in Step 5 of Chart 1).

Table 10 gives estimates for feasible moderate (column 3) and feasible maximum (column 5) levels of increase in roof albedo per building type based on field and laboratory experience and in-house knowledge databases. The given values also factor in the effects of dirt accumulation and weathering and thus no cleaning maintenance is assumed. The value of absorptivity (a) is used in equations (3) and (4). Of course, $a=1-\rho$, for opaque building materials. 
Table 10. Assumed roof albedo $(\alpha)$ and feasible increase $(\Delta \alpha)$

\begin{tabular}{|c|c|c|c|c|c|}
\hline 1 & 2 & 3 & 4 & 5 & 6 \\
\hline & 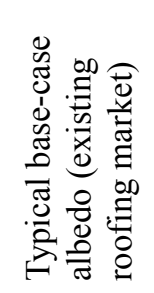 & 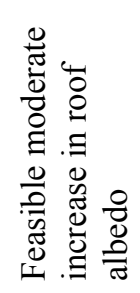 & 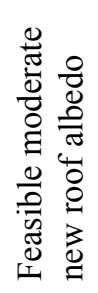 & 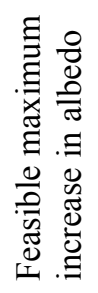 & 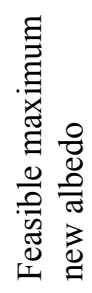 \\
\hline Hospital & .20 & .20 & .40 & .40 & .60 \\
\hline Housing & .20 & .15 & .35 & .30 & .50 \\
\hline Industrial & .30 & .25 & .55 & .40 & .70 \\
\hline Office & .20 & .20 & .40 & .40 & .60 \\
\hline Prison & .15 & .20 & .35 & .40 & .55 \\
\hline Other & .20 & .15 & .35 & .30 & .50 \\
\hline R\&D & .25 & .20 & .45 & .40 & .65 \\
\hline School & .20 & .15 & .35 & .30 & .50 \\
\hline Services & .20 & .20 & .40 & .40 & .60 \\
\hline Storage & .15 & .20 & .35 & .40 & .55 \\
\hline Utility & .20 & .25 & .45 & .50 & .70 \\
\hline
\end{tabular}

Finally, one last piece of information is needed before equations (3) and (4) can be used, and that is total roof area by building type across the states. The data obtained from FEMP is aggregated on a regional basis, as mentioned earlier in this document. In the spreadsheet calculator, the data is manipulated and recast on a State basis as shown in Table 11. The purpose of this step is to develop better means of correlating the facility square footage to weather data (using States as a surrogate for weather). Even though states are still large in area and can have varied weather and microclimates within, the present step is at least an improvement over the FEMP regional scales, which cannot be easily associated with weather types. Thus Table 11 gives a weighting basis for further breaking down the data by FEMP building types and by state. Square footage given in the table is in thousands. 
Table 11. Federal/FEMP building type square footage by State.

\begin{tabular}{|c|c|c|c|c|c|c|c|c|c|c|c|}
\hline State $\downarrow$ & 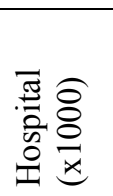 & 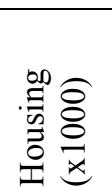 & 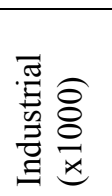 & 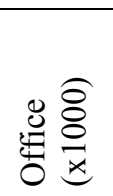 & 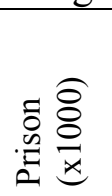 & 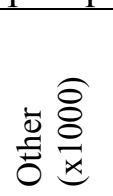 & ڤે & 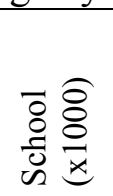 & 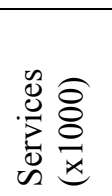 & 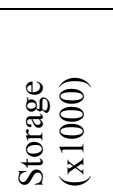 & 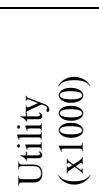 \\
\hline \multicolumn{12}{|c|}{ FEMP Region: Northeast } \\
\hline Massachusetts & 3542 & 16739 & 608 & 12645 & 0 & 655 & 3779 & 3479 & 4656 & 3550 & 0 \\
\hline $\begin{array}{l}\text { New } \\
\text { Hampshire }\end{array}$ & 367 & 2725 & 3 & 1600 & 0 & 372 & 154 & 277 & 3042 & 1022 & 0 \\
\hline New York & 7868 & 19556 & 2384 & 30499 & 2 & 1592 & 4364 & 4641 & 9921 & 10569 & 0 \\
\hline Rhode Island & 489 & 3917 & 0 & 1702 & 0 & 366 & 1400 & 1332 & 1642 & 2503 & 0 \\
\hline Connecticut & 988 & 5189 & 708 & 3058 & 203 & 134 & 330 & 793 & 1311 & 459 & 0 \\
\hline Maine & 148 & 3753 & 0 & 2749 & 0 & 292 & 3 & 432 & 2962 & 1016 & 0 \\
\hline Vermont & 281 & 8 & 0 & 668 & 0 & 61 & 9 & 19 & 251 & 61 & 0 \\
\hline \multicolumn{12}{|c|}{ FEMP Region: Mid Atlantic } \\
\hline $\mathrm{DC}$ & 3313 & 4319 & 1432 & 41638 & 0 & 1842 & 4242 & 644 & 3726 & 2671 & 10 \\
\hline Delaware & 438 & 2270 & 0 & 845 & 0 & 36 & 9 & 389 & 2230 & 637 & 0 \\
\hline New Jersey & 2028 & 11588 & 11 & 9049 & 110 & 787 & 3593 & 2309 & 6714 & 12753 & 0 \\
\hline Virginia & 3592 & 36386 & 2739 & 33835 & 353 & 4328 & 4085 & 7193 & 23054 & 26560 & 0 \\
\hline West Virginia & 1029 & 240 & 6 & 1845 & 823 & 215 & 404 & 320 & 485 & 269 & 0 \\
\hline Maryland & 5099 & 22879 & 2102 & 18161 & 23 & 2163 & 17505 & 6112 & 11869 & 8133 & 0 \\
\hline Pennsylvania & 5202 & 6785 & 1889 & 17954 & 942 & 1190 & 2459 & 1770 & 10745 & 22649 & 0 \\
\hline \multicolumn{12}{|c|}{ FEMP Region: Southeast } \\
\hline $\begin{array}{l}\text { North } \\
\text { Carolina }\end{array}$ & 3019 & 13218 & 604 & 10543 & 280 & 1266 & 166 & 3129 & 11650 & 7920 & 0 \\
\hline Alabama & 1405 & 2330 & 601 & 5253 & 537 & 105 & 3862 & 863 & 2051 & 1639 & 0 \\
\hline Georgia & 3579 & 19051 & 91 & 21122 & 622 & 1401 & 1395 & 5635 & 13773 & 18442 & 0 \\
\hline Kentucky & 2590 & 7446 & 7917 & 8152 & 1400 & 281 & 173 & 2312 & 4898 & 7378 & 0 \\
\hline Puerto Rico & 536 & 51 & 0 & 583 & 0 & 25 & 36 & 102 & 10 & 42 & 0 \\
\hline $\begin{array}{l}\text { South } \\
\text { Carolina }\end{array}$ & 2316 & 19788 & 2283 & 5917 & 0 & 468 & 566 & 2513 & 6524 & 4312 & 0 \\
\hline Florida & 5509 & 27099 & 1084 & 14900 & 492 & 1342 & 6817 & 4236 & 22691 & 7502 & 0 \\
\hline Mississippi & 1833 & 8655 & 5 & 4123 & 0 & 518 & 2901 & 2539 & 3522 & 2878 & 0 \\
\hline Arkansas & 2893 & 5756 & 391 & 4029 & 17 & 249 & 605 & 681 & 3051 & 3669 & 0 \\
\hline Tennessee & 2950 & 3049 & 3335 & 9156 & 234 & 1442 & 4600 & 2051 & 7265 & 12012 & 0 \\
\hline Virgin Islands & 0 & 22 & 0 & 152 & 0 & 12 & 0 & 0 & 3 & 2 & 0 \\
\hline \multicolumn{12}{|c|}{ FEMP Region: Midwest } \\
\hline Missouri & 2583 & 9434 & 5151 & 12596 & 0 & 310 & 162 & 1591 & 2826 & 6559 & 0 \\
\hline Ohio & 3981 & 4330 & 15701 & 14254 & 0 & 653 & 8107 & 1555 & 8617 & 14571 & 0 \\
\hline Wisconsin & 2630 & 3981 & 2746 & 3379 & 417 & 115 & 778 & 639 & 1772 & 1658 & 29 \\
\hline Indiana & 1352 & 5114 & 2997 & 6732 & 744 & 414 & 865 & 1180 & 4125 & 7357 & 0 \\
\hline Iowa & 657 & 299 & 1382 & 2177 & 0 & 147 & 685 & 529 & 1135 & 2440 & 0 \\
\hline Illinois & 4638 & 12856 & 3010 & 19277 & 246 & 821 & 3997 & 3628 & 6476 & 11325 & 0 \\
\hline Minnesota & 2666 & 544 & 3018 & 4373 & 142 & 299 & 538 & 680 & 1518 & 1754 & 0 \\
\hline Michigan & 2405 & 8551 & 45 & 7918 & 386 & 787 & 604 & 928 & 3978 & 1824 & 0 \\
\hline \multicolumn{12}{|c|}{ FEMP Region: Central } \\
\hline Colorado & 2734 & 12946 & 2056 & 10857 & 245 & 449 & 1399 & 4058 & 7748 & 8784 & 9 \\
\hline New Mexico & 1617 & 12374 & 658 & 9613 & 0 & 939 & 8226 & 2137 & 6687 & 5289 & 0 \\
\hline Texas & 9718 & 37408 & 8744 & 32241 & 1431 & 1777 & 2173 & 10232 & 30344 & 28212 & 3 \\
\hline Utah & 818 & 3844 & 301 & 3529 & 0 & 305 & 524 & 457 & 8588 & 9625 & 0 \\
\hline Kansas & 1745 & 13790 & 2878 & 7237 & 1020 & 435 & 78 & 1562 & 4803 & 7099 & 0 \\
\hline Louisiana & 1952 & 11083 & 5157 & 8406 & 12 & 171 & 665 & 1440 & 6793 & 5639 & 0 \\
\hline Montana & 359 & 2792 & 15 & 1833 & 0 & 1333 & 159 & 246 & 1110 & 780 & 344 \\
\hline
\end{tabular}




\begin{tabular}{|l|r|r|r|r|r|r|r|r|r|r|r|}
\hline North Dakota & 765 & 10017 & 54 & 1247 & 0 & 1765 & 139 & 944 & 4052 & 2030 & 0 \\
\hline Oklahoma & 1962 & 10300 & 2950 & 7381 & 359 & 547 & 531 & 3145 & 11688 & 14357 & 0 \\
\hline South Dakota & 993 & 4558 & 0 & 2163 & 0 & 270 & 41 & 1361 & 2424 & 865 & 0 \\
\hline Wyoming & 440 & 2882 & 1 & 7193 & 0 & 263 & 625 & 180 & 2957 & 684 & 0 \\
\hline Nebraska & 1151 & 5029 & 2556 & 3353 & 0 & 788 & 239 & 202 & 2745 & 1088 & 0 \\
\hline FEMP Region: Western \\
\hline Alaska & 1038 & 18068 & 46 & 6494 & 15 & 717 & 383 & 417 & 8211 & 5158 & 0 \\
\hline Arizona & 2268 & 17629 & 695 & 6514 & 837 & 425 & 1270 & 2979 & 7376 & 6403 & 0 \\
\hline California & 12090 & 86906 & 6407 & 52671 & 1158 & 8902 & 20462 & 13619 & 73140 & 68091 & 33 \\
\hline Washington & 3807 & 15130 & 1651 & 30749 & 47 & 3443 & 1773 & 3604 & 15786 & 11317 & 0 \\
\hline Guam & 0 & 0 & 0 & 9 & 0 & 0 & 0 & 0 & 0 & 0 & 0 \\
\hline Hawaii & 1183 & 26300 & 72 & 9007 & 13 & 2142 & 74 & 1107 & 13872 & 10593 & 0 \\
\hline Idaho & 460 & 2955 & 708 & 2194 & 0 & 321 & 1617 & 296 & 2163 & 1850 & 0 \\
\hline Nevada & 493 & 4409 & 414 & 2375 & 62 & 190 & 67 & 297 & 3454 & 8856 & 0 \\
\hline Oregon & 1169 & 1257 & 58 & 3643 & 0 & 317 & 505 & 360 & 1311 & 3714 & 0 \\
\hline
\end{tabular}

Using values from all tables in this document, the nationwide energy use in Federal buildings is computed as follows, where in this case, " $i$ " is the State, " $\mathrm{j}$ " is the building type, " $k$ " is HVAC system type, and " $\mathrm{S}$ " is saturation of HVAC equipment of type " $\mathrm{k}$ ". " $\mathrm{A}$ " and "N" retain their earlier meanings.

$$
\begin{aligned}
E_{n} & =\sum E(i, j, k)=\sum\{F(i, j, k) \times A(j) / N(j) \times S(i, j, k)\} \\
F(i, j, k) & =C_{o}(i, j, k)+C_{1}(i, j, k) a+C_{2}(i, j, k) U+C_{3}(i, j, k) U ~ a
\end{aligned}
$$

Then the savings from cool roofs are computed by repeating the above calculations for a scenario with cool roofs and subtracting the total from the values of the baseline energy usage.

\subsection{The spreadsheet calculator}

A simple MS Excel spreadsheet was developed along with this document and can be found on the included floppy disk. The purpose of the "calculator" is to provide a simple tool for use by FEMP in estimating the potential building-scale and national impacts of cool roofs on energy use in FEMP facilities. The spreadsheet can produce results by building type, state, or nationwide basis. As region- and building-specific coefficients and numbers become available, as well as more specific energy costs, HVAC saturation levels, and so on, this calculator can be updated constantly. Currently, the spreadsheet assumes national average energy costs, that is, $\$ 0.08 \mathrm{kWh}^{-1}$ and $\$ 0.65$ therm $^{-1}$.

The spreadsheet is currently designed just to produce results for a first-cut assessment and can be improved upon, quite significantly in follow-on efforts. Currently, the calculator consists of the following components: 1) square footage of building types by state, 2) assumed typical number of floors per building type, 3) HVAC saturation per building type and state for heating and cooling equipment, 4) assumed existing roof albedo for building types as well as two levels of assumed increases in albedo (feasible moderate and feasible maximum), 5) energy rates (electricity and gas), 6) various coefficients for equations (3) and (4), and parameters for calculating the cost of conserved energy (CCE) which will be defined and explained in Section 7. 
As mentioned earlier, to use the calculator initially, a mapping of climate types, cities, and states is needed. This is because past studies did not encompass every single US state. Some similarity therefore has to be assumed and used in the mapping. In the current state of the calculator, the following mapping of the regression coefficients from Table 8 (for use in equations (3) and (4)) was done (see Table 12). That is, for the states shown in columns 1 or 3 of Table 12, the coefficients were those from the corresponding location in columns 2 or 4 .

Table 12. Mapping of states and climate types.

\begin{tabular}{|c|c|c|c|}
\hline 1 & 2 & 3 & 4 \\
\hline FEMP State & Use coefficients from: & FEMP State & Use coefficients from: \\
\hline Massachusetts & \multirow{2}{*}{ Halifax } & North Carolina & \multirow{5}{*}{ Atlanta } \\
\hline New Hampshire & & Alabama & \\
\hline New York & \multirow[t]{15}{*}{ Minneapolis } & Georgia & \\
\hline Rhode Island & & Kentucky & \\
\hline Connecticut & & Tennessee & \\
\hline Maine & & Puerto Rico & \multirow[t]{2}{*}{ Tampa } \\
\hline Vermont & & South Carolina & \\
\hline District of Columbia & & Florida & \multirow[t]{3}{*}{ Miami } \\
\hline Delaware & & Virgin Islands & \\
\hline New Jersey & & Guam & \\
\hline Virginia & & Mississippi & \multirow[t]{2}{*}{ Lake Charles } \\
\hline West Virginia & & Louisiana & \\
\hline Maryland & & Arkansas & \multirow[t]{5}{*}{ Amarillo } \\
\hline Pennsylvania & & Missouri & \\
\hline Wisconsin & & Colorado & \\
\hline Minnesota & & Kansas & \\
\hline Michigan & & Oklahoma & \\
\hline Ohio & \multirow[t]{9}{*}{ Boise } & New Mexico & \multirow[t]{2}{*}{ Fort Worth } \\
\hline Indiana & & Texas & \\
\hline Iowa & & Alaska & Anchorage \\
\hline Illinois & & Arizona & \multirow[t]{2}{*}{ Phoenix } \\
\hline Montana & & Nevada & \\
\hline South Dakota & & California & San Bernardino \\
\hline Wyoming & & Washington & Seattle \\
\hline Nebraska & & Hawaii & Honolulu \\
\hline Idaho & & Oregon & Portland \\
\hline North Dakota & Bismarck & & \\
\hline
\end{tabular}

Note that the mapping assumed in Table 12, while handy, can be a source of serious error, especially in calculating energy savings, CCE, and related econometrics. For example, there are no coefficients appropriate for the Northeastern U.S., thus the use of Minneapolis (column 2) to represent 15 states in that area (column 1) which can introduce significant errors. The same is seen, but to a lesser degree, with Boise, Atlanta, and Amarillo. Using San Bernardino as an average for California may also introduce errors. However, this represents all the available data thus far that can be used in formulating this initial "template" calculator. Obviously, there is room for significant improvements in data site-specificity.

An example application of the calculator is given in the following section (Section 7). 


\section{COST EFFECTIVENESS}

In previous studies, the cost effectiveness of cool roofs was estimated via a number of parameters. These included 1) the annual decrease in cooling electricity consumption, 2) annual increase in heating electricity and/or gas, 3) net present value of net energy savings, 4) cost savings from downsizing cooling equipment, 5) the incremental cost for cool roofs, 6) peak cooling electricity demand reduction, 7) expenditure decrease from participation in a load curtailment program, 8) expenditure decrease from participation in a reflective-roof rebate program, and 9) savings in material and labor costs from extended life of roof surface and insulating materials.

In this study, a more direct way of evaluating the benefits is being proposed to assess the costeffectiveness of cool roofs on FEMP facilities and buildings. This is the cost of conserved energy (CCE) used in conjunction with the present value of heating penalties. Of course this does not account for additional benefits from 4, 6, 7, and 8 above. Depending on use, it may account for item 9 , above. This metrics is defined with the following three equations:

$$
\begin{aligned}
& \mathrm{CCE}=[\Delta \mathrm{I} / \Delta \mathrm{E}] \times\left[\mathrm{i} /\left\{1-(1+\mathrm{i})^{-\mathrm{n}}\right\}\right. \\
& \Delta \mathrm{I}=\left(\mathrm{A}_{\mathrm{r}} \times \mathrm{c}_{\mathrm{i}}\right)+\mathrm{pHP}-\mathrm{-}_{\mathrm{C}}-----(6) \\
& \mathrm{pHP}=\mathrm{A}\left\{(1+\mathrm{i})^{\mathrm{n}}-1\right\} /\left\{\mathrm{i}(1+\mathrm{i})^{\mathrm{n}}\right\}-------(7)
\end{aligned}
$$

In these equations, $\Delta \mathrm{I}$ is the additional cost (investment) incurred in upgrading to cool roofs and $\Delta \mathrm{E}$ is the annual cooling energy savings (note that the cost of heating penalties is included in the term $\Delta \mathrm{I})$. " $\mathrm{i}$ " is the "interest" or compounding rate, $\mathrm{n}$ is the life span of the cool roof, $\mathrm{A}_{\mathrm{r}}$ is roof area for a particular roof type and state, $\mathrm{c}_{\mathrm{i}}$ is incremental cool roof cost for building type and state, and $\mathrm{pHP}$ is the present value of annual heating energy penalty (A) for each state and FEMP building type.

Of course, if no additional costs are incurred (no incremental costs) when selecting a cool roof instead of a conventional one (such as during construction or reproofing) then all savings are pure benefits and there is no need to calculate CCE. However, if incremental costs are incurred, then the CCE must be calculated to help in selecting the most appropriate cool roof options.

To provide an example, the calculator is used in this section to compute a nationwide assessment of CCE, assuming a rate (i) of $6 \%$. In the example, it is also assumed that pHP varies according to roof and building types. In addition, the incremental costs of cool roofs with respect to noncool ones are assumed as in Table 13, which is a modification of a combination of tables 4 and 5. Furthermore, Table 13 was recast to match the FEMP building categories. Again, the assumptions made here are for the sake of using the calculator in exemplifying the potential CCE related to FEMP cool roofs program, but can be improved upon in the future.

Because only cooling energy is reduced (heating energy can increase) when cool roofs are applied, CCE is computed only for cooling energy (as $\$ \mathrm{kWh}^{-1}$ ) while including the heating energy penalty in the investment term $\Delta \mathrm{I}$ (as an additional cost), as in equation (6). But because 
heating penalty is accrued annually over the life span of the cool roof, a present value of heating penalty (pHP) is calculated and included in term $\Delta \mathrm{I}$. Table 13 lists assumed expected life spans and incremental costs for common cool-roof types (these are assumptions used in the example calculations). The numbers are obtained from averaging and combining numbers in Tables $\mathbf{4}$ and 5.

Table 13. Assumed incremental costs and life spans of cool roofs.

\begin{tabular}{|c|c|c|c|c|c|}
\hline \multirow[b]{2}{*}{ FEMP } & \multirow[b]{2}{*}{ Proposed cool roof version } & \multicolumn{2}{|c|}{$\begin{array}{l}\text { Incremental } \\
\text { cost over } \\
\text { conventional } \\
\$ / \mathrm{ft}^{2}\end{array}$} & \multicolumn{2}{|c|}{$\begin{array}{l}\text { Total Life } \\
\text { span } \\
\text { (years) }\end{array}$} \\
\hline & & low & high & low & high \\
\hline Hospital & $\begin{array}{l}\text { BUR with asphalt }+ \text { cementitious } \\
\text { coatings OR BUR with white } \\
\text { gravel }\end{array}$ & 0.05 & 0.15 & 12 & 25 \\
\hline Housing & Light-color concrete tile & 0.00 & 0.05 & 10 & 20 \\
\hline Industrial & Metal roof with light-color paint & 0.00 & 0.05 & 20 & 50 \\
\hline Office & $\begin{array}{l}\text { BUR with asphalt }+ \text { cementitious } \\
\text { coatings OR modified bitumen }\end{array}$ & 0.00 & 0.05 & 12 & 25 \\
\hline Prison & Light-color concrete tile & 0.00 & 0.05 & 15 & 30 \\
\hline Other & $\begin{array}{l}\text { BUR with asphalt }+ \text { cementitious } \\
\text { coatings }\end{array}$ & 0.05 & 0.10 & 12 & 25 \\
\hline R\&D & $\begin{array}{l}\text { BUR with asphalt }+ \text { cementitious } \\
\text { coatings OR BUR with white } \\
\text { gravel }\end{array}$ & 0.10 & 0.20 & 12 & 25 \\
\hline School & $\begin{array}{l}\text { BUR with asphalt }+ \text { cementitious } \\
\text { coatings OR BUR with white } \\
\text { gravel }\end{array}$ & 0.00 & 0.05 & 12 & 25 \\
\hline Services & Metal roof with light-color paint & 0.00 & 0.05 & 20 & 50 \\
\hline Storage & Metal roof with light-color paint & 0.00 & 0.05 & 20 & 50 \\
\hline Utility & Light-color concrete tile & 0.00 & 0.05 & 20 & 40 \\
\hline
\end{tabular}

Table 13 thus involves simplifying assumptions when matching roof types and costs with FEMP building types. In the calculator, the user can enter state-specific and building-specific information, roof types, life span, and costs, if these become available. But for the example exercise here, the generic values in the tables above will be used.

In Table 13, the "low" end of the range is assumed to correspond to "scenario 1" in the calculator (feasible moderate increase in albedo), whereas the "high" end of the range is assumed to correspond to "scenario 2" (feasible maximum increase in albedo). This implies that the whiter (cooler) the roof is, the more expensive it gets. This may not always be true but the assumption is used as such in the first example calculation provided here. Also, for this initial estimation, the incremental costs of cool roofs are assumed to be State-independent. State-by-state costs can be entered in the calculator when they become known in the future. 
Clearly, FEMP should encourage use of cool roofs in new construction and during regularly scheduled re-roofing to keep incremental costs down. In estimating cost effectiveness, only the incremental initial cost of changing the albedo of the roof from a low value to a high value was considered in the present calculations (calculator). Additional expenditure would be required if a building owner wished to maintain the cool roof's albedo at its initial high level (e.g., $\geq 0.70$ ). That additional cost has not been factored into the present analysis because the simulated energy savings are based on a degraded albedo that assumes no additional maintenance. And, of course, material and labor costs for roofing projects vary from one contractor to another.

Thus using the combinations of options in Table 13, as well as expected features and roof types per building types, the calculations in the first set yield a nationwide FEMP inventory average CCE of $\$ 0.069 / \mathrm{kWh}$ in scenario 1 and $\$ 0.094 / \mathrm{kWh}$ for scenario 2 . Assuming a national average cost of $\$ 0.08 / \mathrm{kWh}$, these calculations suggest that scenario 1 (moderate albedo increase) is beneficial if adopted by FEMP whereas scenario 2 (high albedo increase) may be on the borderline because of increased cost of more reflective cool roofs. However, this analysis may be misleading because of the assumptions made above regarding cool roof types. That is, expensive cool roof types were selected. In the second set of calculations (where cool roofs last roughly twice as long as non-cool ones), the CCE is 0 (actually negative). This means that cool roof strategies are extremely efficient due to saving energy and also because the avoided cost of materials for re-roofing the conventional non-cool roofs pays for itself enormously (without even accounting for labor costs)!

To provide more realistic estimates, a sensitivity analysis was performed to elucidate a range of CCE due to various albedo and cost combinations. For this analysis, the assumption was made that all roofs in the FEMP inventory have an average life span of 15 years in option 1, 30 years in option 2, and 45 years in option 3 (the latter is rather high but used here for a theoretical calculation). These are shown in Table 14. In addition, the assumption was that scenarios 1 and 2 above would represent a range of possible albedo increases. The roofs are also assumed to have a nationwide average R-11 insulation. With that in mind, a stepwise increase in the incremental cost of cool roofs was used in the sensitivity analysis. The results are summarized in Table 14. The light gray region highlight CCE $\leq \$ 0.08 \mathrm{ft}^{-2}$, whereas the dark gray area shows regions where CCE becomes extremely prohibitive. Thus the sensitivity analysis suggests that the cutoff incremental cost in the first set of calculations is about $\$ 0.06 \mathrm{ft}^{-2}$.

Example results in Table 14 are for general illustration purposes and not meant to be used directly since they involve various assumptions and non-linear changes in certain terms of the equations. Actual calculations must be performed on a case-by-case basis with region-specific information. 
Table 14. Computed CCE for various combinations of roof life span and incremental costs.

\begin{tabular}{|c|c|c|c|c|c|c|c|}
\hline \multirow{9}{*}{ 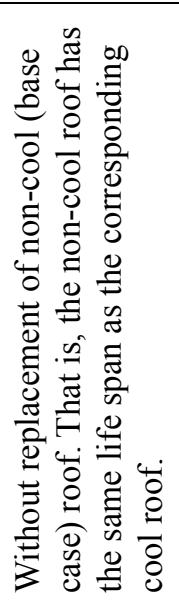 } & \multirow{3}{*}{$\begin{array}{l}\text { Nationwide } \\
\text { average } \\
\text { incremental } \\
\text { cost for } \\
\text { cool roofs } \\
\left(\$ / \mathrm{ft}^{2}\right)\end{array}$} & \multicolumn{6}{|c|}{ CCE (\$/kWh) FEMP facilities nationwide average } \\
\hline & & \multicolumn{2}{|c|}{15 years roof life span } & \multicolumn{2}{|c|}{30 years roof life span } & \multicolumn{2}{|c|}{45 years roof life span } \\
\hline & & Scenario 1 & Scenario 2 & Scenario 1 & Scenario 2 & Scenario 1 & Scenario 2 \\
\hline & & 0 & 0 & 0 & 0 & 0 & 0 \\
\hline & .02 & .08 & .05 & .06 & .04 & .06 & .04 \\
\hline & .04 & .13 & .08 & .10 & .06 & .09 & .06 \\
\hline & .06 & .17 & .10 & .13 & .08 & .12 & .07 \\
\hline & .08 & & & .17 & .10 & .15 & .09 \\
\hline & .10 & & & & & .18 & .10 \\
\hline
\end{tabular}

\section{CONCLUSIONS}

This document summarizes initial estimates for the potential benefits of cool roofs on Federal buildings and facilities. It provides a basis for building-scale estimations and an example calculation for nationwide impacts assessments. Along with this document, a preliminary spreadsheet "calculator" was devised to help FEMP estimate potential energy and cost savings of cool roofs. This document and companion calculator form the basis for a first step towards longer-term research and modeling to assess the detailed potential benefits of cool roofs in FEMP facilities and buildings.

Assuming an average nation-wide insulation level of R-11 for FEMP building roofs, the calculations in this document suggest nationwide savings in energy costs of $\$ 16 \mathrm{M}$ and $\$ 32 \mathrm{M}$ for two scenarios of increased roof albedo (moderate and high), respectively. The savings correspond to about $3.8 \%$ and $7.5 \%$ of the base energy costs for FEMP facilities and include the increased heating energy use (penalties) in winter. This document also shows that to keep the cost of conserved energy under $\$ 0.08 \mathrm{kWh}^{-1}$ as a nationwide average, the affordable incremental cost for cool roofs for Federal buildings should not exceed $\$ 0.06 \mathrm{ft}^{-2}$ if cool roofs have the same life span as non-cool roofs. If cool roofs have longer life spans than non-cool roofs (which is usually the case), then the costs of re-roofing non-cool roofs must be factored in. In this case, the cutoff incremental cost for cool roofs can be much larger to keep CCE under $\$ 0.08 \mathrm{kWh}^{-1}$. As mentioned in the document, there is a whole range of options in between these ends. This does not even account for labor costs associated with re-roofing of non-cool roofs. Thus there seems to be significant benefits from implementing cool roofs in FEMP facilities and buildings. 


\section{REFERENCES}

Akbari, H. 1998, "Cool roofs save energy", ASHRAE Technical Data Bulletin, Volume 14, No. 2, January 1998, pp. 1-6.

Akbari, H., Konopacki, S.J, Eley, C.N., Wilcox, B.A., Van Geem, M.G., and Parker, D.S. (1998). "Calculations for reflective roofs in support of Standard 90.1", ASHRAE Technical Data Bulletin, Volume 14, No. 2, January 1998, pp. 56-67.

Akbari, H., Bretz, S.E., Taha, H.G., Kurn, D.M., and Hanford, J.W., 1997, "Peak power and cooling-energy savings of high-albedo roofs", Energy and Buildings, 25(2) (1997).

Akbari, H., Bretz, S.E., Hanford, J.W., Kurn, D.M., Fishman, B.L., Taha, H.G., and Bos, W. 1993, "Monitoring peak power and cooling-energy savings of shade trees and white surfaces in the Sacramento Municipal Utility District (SMUD) service area: Data analysis, simulations, and results", Lawrence Berkeley National Laboratory Report No. 34411.

Bretz, S., Akbari, H., and Rosenfeld, H., 1997, "Practical issues for using solar-reflective materials to mitigate urban heat islands"' Lawrence Berkeley National Laboratory Report No. 38170, Berkeley, California.

Builder, 1995, "Roofing”. Builder Magazine, April 1995, pp. 255-257.

Building Energy Simulation Group (1990), "Overview of the DOE-2 Building Energy Analysis Program, Version 2.1D, Lawrence Berkeley National Laboratory Report No. 19735, Rev.1, Berkeley, California.

Freedonia Group, 1997, "Roofing to 2001", The Freedonia Group Report 886, Cleveland, Ohio.

Hildebrandt, E.W., Bos, W., and Moore, R., 1998, "Assessing the impacts of white roofs on building energy loads", ASHRAE Technical Data Bulletin, Volume 14, No. 2, January 1998, pp. 28-36.

Konopacki, S., Akbari, H., Gabersek, S., Pomerantz, M., and Gartland, L., 1997, "Cooling energy savings potentials of light-colored roofs for residential and commercial buildings in 11 U.S. metropolitan areas", Lawrence Berkeley National Laboratory Report No. 39433.

Levinson, R.M, H. Akbari, and S. J. Konopacki, 2002, "Inclusion of cool roofs in non-residential Tilte-24 prescriptive requirements", PG\&E Code Proposals, 2005 Title 24 Building Energy Efficiency Standards Update. A draft LBNL report.

Lufkin, P.S. and Pepitone, A.J., 1997, The Whitestone building maintenance and repair cost reference 1997, $3^{\text {rd }}$ annual edition, Whitestone Research, Seattle, WA.

NRCA 1998, "Data on life expectancies of roofing materials used on homes", Roofing, Siding, Insulation, November (1998), pp. 44.

Parker, D.S., Sherwin, J.R., and Sonne, J.K., 1998, "Measured performance of a reflective roofing system in a Florida commercial building", ASHRAE Technical Data Bulletin, Volume 14, No. 2, January 1998, pp. 7-12. 
Parker, D.S., Barkaszi, S.F., Chandra, S., and Beal, D.J., 1995, "Measured cooling energy savings from reflective roofing systems in Florida: Field and laboratory research results", Proceedings, Thermal Performance of the Exterior Envelopes of Buildings VI, ASHRAE, Atlanta.

Taha, H., Konopacki, S., and Akbari H., 1996, "Impacts of lowered urban air temperatures on precursor emission and ozone air quality", Journal of the Air \& Waste Management Association, Vol. 48, pp. 860-865.

Taha, H., 1997, "Modeling the impacts of large-scale albedo changes on ozone air quality in the South Coast Air Basin", Atmospheric Environment, Vol. 31, No. 11, pp.1667-1676 (1997).

Taha, H., Konopacki, S., and Gabersek, S., 1999, "Impacts of large-scale surface modifications on meteorological conditions and energy use: A 10-region modeling study", Theoretical and Applied Climatology, Vol. 62, pp. 175-186 (1999).

Taha, H., Sailor, D., and Akbari, H., 1992, "High-albedo materials for reducing building cooling energy use”, Lawrence Berkeley National Laboratory Report No. 31721, UC-350.

Western Roofing, 2001, "The growing western roofing market", Western Roofing Insulation and Siding Magazine, http://www.westernroofing.net. 